\title{
Thrombosis Risk Associated with Head and Neck Cancer: A Review
}

\author{
Pierre Haen 1,2 (D), Diane Mege 1,3, Lydie Crescence ${ }^{1}$, Françoise Dignat-George ${ }^{1,4}$, \\ Christophe Dubois ${ }^{1}$ and Laurence Panicot-Dubois ${ }^{1, *}$ D \\ 1 Aix Marseille Univ, INSERM 1263, INRA, Center for CardioVascular and Nutrition Research (C2VN), \\ 27 Boulevard Jean Moulin, 13385 Marseille, France; pierre.haen@yahoo.fr (P.H.); \\ DIANE.MEGE@ap-hm.fr (D.M.); Lydie.crescence@univ-amu.fr (L.C.); \\ Francoise.dignat-george@univ-amu.fr (F.D.-G.); christophe.dubois@univ-amu.fr (C.D.) \\ 2 Department of Maxillo-Facial Surgery, Army Training Hospital, Laveran, 13013 Marseille, France \\ 3 Department of Digestive Surgery, Timone University Hospital, AP-HM, 13005 Marseille, France \\ 4 Laboratoire d'Hématologie, Centre Hospitalo-Universitaire Conception, 385 Boulevard Baille, \\ 13385 Marseille, France \\ * Correspondence: laurence.panicot-dubois@univ-amu.fr; Tel.: +33-491-835-561
}

Received: 1 May 2019; Accepted: 7 June 2019; Published: 11 June 2019

\begin{abstract}
Venous thromboembolism (VTE) is a common complication for cancer patients. VTE-associated risk varies according to the type of tumor disease. Head and neck cancer is a common cancer worldwide, and most tumors are squamous cell carcinomas due to tobacco and alcohol abuse. The risk of VTE associated with head and neck (H\&N) cancer is considered empirically low, but despite the high incidence of $H \& N$ cancer, few data are available on this cancer; thus, it is difficult to state the risk of VTE. Our review aims to clarify this situation and tries to assess the real VTE risk associated with H\&N cancer. We report that most clinical studies have concluded that there is a very low thrombosis risk associated with H\&N cancer. Even with the biases that often exist, this clinical review seems to confirm that the risk of VTE was empirically hypothesized. Furthermore, we highlight that H\&N cancer has all the biological features of a cancer associated with a high thrombosis risk, including a strong expression of procoagulant proteins, modified thrombosis/fibrinolysis mechanisms, and secretions of procoagulant microparticles and procoagulant cytokines. Thus, this is a paradoxical situation, and some undiscovered mechanisms that could explain this clinical biological ambivalence might exist.
\end{abstract}

Keywords: Head and neck neoplasms; venous thromboembolism; squamous cell carcinoma; thrombosis; cancer

\section{Introduction}

The association between cancer and venous thromboembolism (VTE) has been known since its historical description by Trousseau [1] and Bouillaud [2] in the 19th century. Since then, several studies have established that thrombosis is a common complication for cancer patients, and it has been estimated that patients with cancer have an approximately sevenfold higher risk of VTE than those without cancer [3]. Several biological mechanisms have been highlighted and focus on a hypercoagulable state induced by malignant cells [4], including: expression of procoagulant protein [5], release of procoagulant microparticles [6], induced secretion of procoagulant inflammatory cytokines [7], and support of a prothrombotic state on platelets, endothelial cells or leucocytes [8]. The VTE risk varies in accordance with cancer type, location, stage and histological grade and classification [9]. Additionally, factors related to cancer management, such as surgery, chemotherapy, radiotherapy, hormonal therapy, hospitalization with long-term bed rest, and indwelling venous catheters, further increase the VTE 
risk $[9,10]$. VTE disease is the second cause of mortality in cancer patients [10], following the malignant disease itself. Treatment and prophylaxis of VTE are crucial parts of the global management of patients with cancer. However, even if prophylaxis has a positive effect on the emergence of VTE [11,12], it has not been clearly demonstrated that VTE prophylaxis has an impact on the cancer patients' mortality [11,13]. The main incriminated factor is that antithrombotic treatments are not risk-free and can be responsible for life-threatening hemorrhage, especially in at-risk patients with tumors [12]. VTE prophylaxis can be challenging; therefore, it is essential to perform a thorough assessment of the VTE risk based initially on the cancer characteristics.

Although its incidence has declined in the last ten years, head and heck $(\mathrm{H} \& \mathrm{~N})$ cancer is still among the most common cancers worldwide. With approximately 500,000 new cases and 150,000 deaths per year in the world, $\mathrm{H} \& \mathrm{~N}$ cancer ranks between the 8th and 10th most frequently occurring cancer, depending on the country [14-16]. H\&N cancer includes oral cavity cancer (lip, tongue, mucosa and gingivae), pharyngeal cancer (oropharynx, nasopharynx, hypopharynx), laryngeal cancer, thyroid cancer and some cancer of the upper part of the esophagus. Oral cavity cancer is the most frequent localization [17]. More than $90 \%$ of H\&N cancers are squamous cell carcinomas (SCCs) [18]. Historically, head and neck squamous cell carcinoma (H\&N SCC) risk factors are tobacco use and alcohol abuse, but human papillomavirus has recently been identified as a risk factor, especially for tongue localization [19]. Despite H\&N SCC being a common disease, it is difficult to determine the risk of thrombosis. Indeed, the available data in the literature seem to be contradictory, with most studies suggesting a poor or nonexistent thrombosis risk associated with H\&N SCC and some studies supporting a notable associated risk. Moreover, few specific data are available, and confounding factors are often present in those studies, which contributes to why the conclusions remain unclear.

Our review aims to clarify the available findings on this topic, especially through biological studies that can support clinical observations.

\section{The lack of Clinical Evidence}

Thrombosis risk associated with H\&N cancer is empirically rated to be very weak or, in fact, be nonexistent $[20,21]$. However, an overview of the literature tells us that the situation is not black and white, and it seems difficult to obtain evidence-based proof, notably because of numerous biases. We looked at the major clinical studies that reported VTE associated with H\&N cancer and assessed the risk of thrombosis. A literature review has been carried out with three main focuses:

Analysis of studies that assessed the incidence of cancer diagnosis following a VTE and those that evaluated the risk according to cancer localization. We focused on H\&N cancer incidence and found that the incidence of H\&N cancer corresponded between $0 \%$ and $1.45 \%$ of all diagnosed cancers. $\mathrm{H} \& \mathrm{~N}$ cancer was almost ranked as the least common cancer following VTE. The data are listed in Table 1.

According to an analysis of studies that assessed the incidence of thromboembolism in patients diagnosed with cancer according to its localization, we studied the specific risk of VTE following H\&N cancer and compared the incidence of VTE with H\&N cancer to that of other cancer localizations. We found an estimated incidence of VTE in H\&N cancer patients from $0.16 \%$ to (more than) $3.125 \%$. The thrombosis risk associated with $\mathrm{H} \& \mathrm{~N}$ cancer was one of the lowest of the studied cancers, except in the Paneesha et al. study, where H\&N cancer was ranked second behind pancreas cancer [22]. The data are listed in Table 2. 
Table 1. Incidence of H\&N cancer diagnosis following VTE.

\begin{tabular}{|c|c|c|c|c|c|c|c|c|}
\hline First Author & Year & Type of Study & Population & $\begin{array}{l}\text { Number of } \\
\text { Patients }\end{array}$ & $\begin{array}{l}\text { Median } \\
\text { Follow-up }\end{array}$ & $\begin{array}{c}\text { Number and per Centage of } \\
\text { H\&N Cancer/All Diagnose } \\
\text { Cancers }\end{array}$ & $\begin{array}{l}\text { Rank } \\
\text { H\&N/Other } \\
\text { Tumor Site }\end{array}$ & Ref \\
\hline Prandoni & 1992 & $\begin{array}{l}\text { Prospective } \\
\text { cohort study }\end{array}$ & $\begin{array}{l}\text { Patient with DVT (deep vein } \\
\text { thrombosis) (unprovoked or secondary } \\
\text { to surgery or fracture) }\end{array}$ & 250 & 2 years & $0 / 13-0 \%$ & undefined & [23] \\
\hline Piccioli & 2004 & $\begin{array}{l}\text { Prospective } \\
\text { clinical study }\end{array}$ & $\begin{array}{l}\text { Patient with first idiopathic VTE (DVT } \\
\text { or PE) }\end{array}$ & 201 & 2 years & $0 / 24-0 \%$ & undefined & {$[24]$} \\
\hline Trujillo- Santos & 2007 & $\begin{array}{l}\text { Case control } \\
\text { study }\end{array}$ & $\begin{array}{l}\text { Patient with VTE (DVT or PE) and } \\
\text { occult cancer diagnose }\end{array}$ & 14,623 & 3 month & $\begin{array}{l}\text { 1/178-0.56\% } \\
\text { Larynx }\end{array}$ & $15 / 15$ & [25] \\
\hline Sørensen & 2012 & Cohort study & $\begin{array}{l}\text { Patient with superficial and deep VT } \\
\text { and PE }\end{array}$ & 77,247 & 15 years & $\begin{array}{l}\text { 35/6329-0.55\% } \\
\text { Larynx }\end{array}$ & $25 / 25$ & [26] \\
\hline Petterson & 2015 & $\begin{array}{l}\text { Retrospective } \\
\text { cohort study }\end{array}$ & Patient with VTE (DVT and PE) $n=1417$ & 1417 & 13 years & 5/345-1.45\% & $22 / 23$ & {$[27]$} \\
\hline Robin & 2016 & $\begin{array}{l}\text { Experimental } \\
\text { prospective } \\
\text { study }\end{array}$ & $\begin{array}{c}\text { Patient screened by TEP/CT following } \\
\text { DVT and PE }\end{array}$ & 399 & 3 years & $0 / 25-0 \%$ & undefined & {$[28]$} \\
\hline Sun & 2016 & $\begin{array}{l}\text { Retrospective } \\
\text { case control } \\
\text { study }\end{array}$ & Patient with unprovoked VTE & 27,751 & 10 years & 98/27751-0.35\% & $17 / 17$ & [29] \\
\hline Sandén & 2017 & $\begin{array}{l}\text { Retrospective } \\
\text { cohort study }\end{array}$ & $\begin{array}{l}\text { Patient with diagnostic of VTE (primary, } \\
\text { secondary, unprovoked and following } \\
\text { surgery or fracture) }\end{array}$ & 7854 & 5 years & 3/499-0.6\% & $12 / 13$ & {$[30]$} \\
\hline Jara-Palomares & 2017 & $\begin{array}{l}\text { Case control } \\
\text { study }\end{array}$ & Patient with VTE & 5863 & 2 years & $5 / 444-1.13 \%$ & $13 / 14$ & {$[31]$} \\
\hline Delluc & 2018 & $\begin{array}{l}\text { Prospective } \\
\text { cohort study }\end{array}$ & Patient with DVT and PE & 526 & 2 years & $0 / 26-0 \%$ & undefined & {$[32]$} \\
\hline
\end{tabular}


Table 2. Incidence of VTE in patients with diagnosed with H\&N cancer and a comparison to that of the other cancer localizations.

\begin{tabular}{|c|c|c|c|c|c|c|c|c|}
\hline First Author & Year & Type of Study & Population & $\begin{array}{c}\text { Number of } \\
\text { Patient }\end{array}$ & $\begin{array}{l}\text { Median } \\
\text { Follow-up }\end{array}$ & $\begin{array}{l}\text { Number and per Centage of } \\
\text { VTE in H\&N Cancer }\end{array}$ & $\begin{array}{l}\text { Ranked Risk Compared to } \\
\text { Other Cancer Localizations }\end{array}$ & Ref. \\
\hline Levitan & 1999 & $\begin{array}{l}\text { Retrospective } \\
\text { cohort study }\end{array}$ & Patient with diagnosed cancer & $1,211,944$ & 6 years & 35 VTE/20924-0.16\% & $18 / 18$ & [33] \\
\hline Sallah & 2002 & $\begin{array}{l}\text { Retrospective } \\
\text { cohort study }\end{array}$ & Patients with solid tumor 1 & 1041 & 7 years & $3 \mathrm{VTE} / 96-3.125 \%$ & $11 / 11$ & [34] \\
\hline Khorana & 2006 & $\begin{array}{l}\text { Retrospective } \\
\text { cohort study }\end{array}$ & $\begin{array}{l}\text { Patient hospitalized with } \\
\text { neutropenic cancer }\end{array}$ & 66,106 & 7 years & $44 \mathrm{VTE} / 1606-2.74 \%$ & $21 / 21$ & [35] \\
\hline Stein & 2006 & $\begin{array}{l}\text { Retrospective } \\
\text { cohort study }\end{array}$ & $\begin{array}{l}\text { Patients hospitalized with } \\
\text { cancer }\end{array}$ & $40,787,000$ & 20 years & $<5000$ VTE/849000-<0.6\% & $19 / 19$ & [36] \\
\hline Khorana & 2007 & $\begin{array}{l}\text { Retrospective } \\
\text { cohort study }\end{array}$ & Patient with cancer & $1,015,598$ & 8 years & 713 VTE/50898-1.4\% & $21 / 21$ & [37] \\
\hline Paneesha & 2010 & $\begin{array}{l}\text { Retrospective } \\
\text { linkage cohort } \\
\text { study }\end{array}$ & $\begin{array}{l}\text { Patient hospitalized with } \\
\text { cancer and/or VTE }\end{array}$ & 39,618 & 3 years & Data not available, but elevated & $2 / 18$ & [22] \\
\hline Walker & 2012 & Cohort study & $\begin{array}{l}\text { Patient with and without } \\
\text { cancer }\end{array}$ & 660,410 & 2 years & 35 VTE/2078-1.68\% & $24 / 26$ & [38] \\
\hline Chew & 2015 & $\begin{array}{l}\text { Retrospective } \\
\text { cohort study }\end{array}$ & Patient with diagnose cancer & 43,855 & 7 years & $40 \mathrm{VTE} / 4390-\mathbf{0 . 9 1 \%}$ & $21 / 23$ & [39] \\
\hline
\end{tabular}

In an analysis of studies that were specifically interested in thrombosis associated with H\&N cancer, especially following surgery, we found an incidence of VTE in H\&N cancer patients ranging from $0 \%$ to $26.3 \%$. The data are listed in Table 3. 
Table 3. Incidence of VTE in patients with H\&N cancer following treatment (surgery), an analysis of specific studies.

\begin{tabular}{|c|c|c|c|c|c|c|c|}
\hline First Author & Year & Study Design & Population & $\begin{array}{l}\text { Number of } \\
\text { Patient }\end{array}$ & $\begin{array}{l}\text { Median } \\
\text { Follow-up }\end{array}$ & $\begin{array}{l}\text { Number and per Centage } \\
\text { of VTE in H\&N Cancer }\end{array}$ & Ref. \\
\hline Innis & 2009 & $\begin{array}{l}\text { Retrospective } \\
\text { review study }\end{array}$ & $\begin{array}{l}\text { Patients following otolaryngological surgery } \\
\text { with and without malignancy }\end{array}$ & 6122 & 5 years & $5 \mathrm{VTE} / 542-\mathbf{0 . 9 2} \%$ & [40] \\
\hline Hennessey & 2012 & $\begin{array}{l}\text { Retrospective } \\
\text { cross sectional } \\
\text { study }\end{array}$ & Patients following H\&N cancer surgery & 93,663 & 5 years & 1860 VTE /93663-2\% & [41] \\
\hline Thai & 2013 & $\begin{array}{l}\text { Retrospective } \\
\text { review study }\end{array}$ & $\begin{array}{c}\text { Patients following a }>4 \mathrm{~h} 00 \mathrm{H} \& \mathrm{~N} \text { cancer } \\
\text { surgery }\end{array}$ & 134 & 2 years & $\begin{array}{l}2 \text { (confirmed-8 (suspected) } \\
\text { VTE/134-1.4-5.8\% }\end{array}$ & [42] \\
\hline Gavriel & 2013 & $\begin{array}{l}\text { Retrospective } \\
\text { cohort study }\end{array}$ & $\begin{array}{l}\text { Patients following a H\&N cancer surgery, with } \\
\text { and without chemoprophylaxis }\end{array}$ & 1018 & 5 years & $\begin{array}{l}0 \mathrm{VTE} / 1018-0 \% \text { (both } \\
\text { cohort) }\end{array}$ & [43] \\
\hline Clayburgh & 2013 & $\begin{array}{l}\text { Prospective cohort } \\
\text { study }\end{array}$ & Patients following H\&N cancer surgery & 100 & 1 month & 8 VTE $/ 100-8 \%$ & [44] \\
\hline Lodders & 2015 & $\begin{array}{l}\text { Retrospective } \\
\text { cohort study }\end{array}$ & Patients following oral cavity cancer surgery & 233 & 5 years & $1 \mathrm{VTE} / \mathbf{2 3 3 - \mathbf { 0 . 4 1 } \%}$ & [45] \\
\hline Ali & 2015 & $\begin{array}{l}\text { Retrospective } \\
\text { cohort study }\end{array}$ & Patients following H\&N cancer surgery & 413 & 8 years & $12 \mathrm{VTE} / 413-\mathbf{2 . 9 \%}$ & [46] \\
\hline Kakei & 2016 & $\begin{array}{l}\text { Retrospective } \\
\text { descriptive study }\end{array}$ & $\begin{array}{l}\text { Patients following oral cavity cancer surgery } \\
\text { with simultaneous reconstruction }\end{array}$ & 133 & 7 years & 35 VTE/133-26.3\% & [47] \\
\hline Wang & 2017 & $\begin{array}{l}\text { Retrospective } \\
\text { descriptive study }\end{array}$ & $\begin{array}{l}\text { Patients following oral cavity and maxillary } \\
\text { cancer surgery }\end{array}$ & 9724 & 4 years & $14 \mathrm{VTE} / \mathbf{9 7 2 4 - \mathbf { 0 . 1 4 } \%}$ & [48] \\
\hline
\end{tabular}


No matter how the data are reported, many of those studies concluded that there was a very low thrombosis risk associated with head and neck carcinoma, with almost always an evaluated risk defined as the lowest of all studied cancer localizations. However, it is notable that some studies found different results and reported a high thrombosis risk associated with H\&N cancer. These consisted largely of studies specifically oriented on the incidence of VTE and H\&N cancer, as well as the study from Paneesha et al., which was mentioned above. In contrast, Levitan and colleagues [33] and Stein et al. [36] reported rates of VTE incidence in H\&N cancer patients $(0.16 \%$ and $0.6 \%$, respectively) that were lower than in their corresponding control group of hospitalized patients without oncological diseases $(0.57 \%$ and $1 \%$, respectively). This may suggest that $\mathrm{H} \& \mathrm{~N}$ cancer might have a protective effect on VTE [49]. All these facts revealed that there is a somewhat considerable lack of clarity on the incidence of VTE, which seems difficult to efficiently determine.

A possible explanation is that the studies on this topic are subject to confounding factors and that "the perfect" study would probably be impossible to conduct.

The first bias is that most of the studies were interested in H\&N cancer; even if the majority of tumors had the same characteristics, the tumors are heterogeneous, which should lead to some differences in the thrombosis risk. In fact, $\mathrm{H} \& \mathrm{~N}$ cancer is caused by large squamous cell carcinoma (SCC), principally from the oral cavity, oropharynx, hypopharynx and larynx. All of these cancers are relatively close, especially in terms of histopathological features and clinical evolution [50,51]. In contrast, some cancers, such as thyroid tumors or salivary gland tumors, are also included in the $\mathrm{H} \& \mathrm{~N}$ cancer group and are clearly different in terms of the histopathological features, clinical evolution and thrombosis-associated risk. Indeed, it has been clearly shown that adenocarcinomas (thyroid or salivary gland) have a higher thrombosis-associated risk than squamous cell carcinomas [52,53]. The same applies to nasopharyngeal carcinoma, which is a specific tumor that is very undifferentiated and is far from the typical H\&N SCC that has a well-known high thrombosis-associated risk [54].

Second, some risk factors of $\mathrm{H} \& \mathrm{~N}$ cancer are also independent risk factors for an elevated risk of venous thromboembolism. Tobacco use and an age older than 50 years have clearly been identified to be risk factors for H\&N SCC, but these factors are also independent risk factors for VTE [18,55]. The same is true for the male sex, which is also associated with both diseases [56].

Lastly, most reported studies included patients who underwent treatment for their malignancies, and many of these treatments are also known to be independent risk factors of venous thromboembolism. These factors include surgical treatment, a favored treatment for H\&N cancer that is often involves long procedures, especially in cases of simultaneous reconstruction $[47,57,58]$. These factors also include chemotherapy, which has been clearly identified as an independent risk factor for venous thromboembolism $[59,60]$.

In short, this clinical study review has shown that the thrombosis risk associated with H\&N cancer seems to be low, as it has been empirically believed. However, some studies had contradictory outcomes, and we showed that confounding factors exist. Thus, there exists no strong clinical proof to make conclusions about the true risk associated with H\&N cancer or H\&N SCC. The continuation of this work will consist of finding biological arguments that could help to stratify this risk.

\section{Clinical Practice and Recommendations}

Because of a lack of clinical evidence, there is no specific evidence that can serve as a basis for recommendations about the clinical practice of VTE management in H\&N cancer patients. However, general strong evidence-based recommendations are available about VTE management in patients with cancer, especially those reported by the American Society of Clinical Oncology (ASCO), which can be considered as references [11,61]. Some good clinical practices for managing VTE in surgical $H \& N$ patients are also available and are given by societies of H\&N surgeons or ENTs [62,63]. 


\subsection{VTE Diagnosis}

The diagnostic strategies for VTE associated with cancer do not differ from the strategies used to diagnose VTE of other causes. Some of the diagnostic tests include lower limb vein compression ultrasonography for deep venous thrombosis and computed tomography angiography to test for pulmonary embolism; although the ventilation perfusion lung scan is no longer used, this method can be an alternative test [64]. It is not recommended to systematically search for VTE in cancer patients but to only screen patients with clinical signs and risk factors [65]. Some clinical scoring systems could be used to help accomplish this task. The blood D-dimer test would also be useful, particularly because a negative result would permit the exclusion of a VTE diagnosis $[64,66]$.

Ultrasonography of the neck, which can be completed by computed tomography angiography or magnetic resonance imaging with angiography, is indicated in cases of neck thrombosis, especially in cases of internal jugular vein thrombosis [67].

\subsection{VTE Treatment}

Low-molecular-weight heparin (LMWH) is the preferred initial anticoagulation treatment for diagnosed VTE associated with cancer. LMWH is also indicated for long-term anticoagulant treatment. In all cases, treatment that lasts for longer than six months must be discussed and reserved for patients with a high risk of VTE recurrence. The recommended treatment following the first VTE diagnosis should continue for three to six months [68]. The benefit/risk balance must be evaluated before treatment, particularly in regard to the bleeding risk [61]. Vitamin K antagonists (VKAs) can be an alternative for long-term treatment if LMWH is not available or is contraindicated or if the malignancy stabilized and the treatment was completed [11]. Incidentally discovered VTE must be treated similarly [69]. The same treatment would also be indicated for neck vein thrombosis [67].

\subsection{VTE Prophylaxis}

According to the clinical guidelines given by the ASCO, most hospitalized patients with active cancer require thromboprophylaxis throughout hospitalization. This recommendation does not apply to ambulatory patients or patients undergoing minor procedures, unless the patient has a high risk of VTE. The VTE risk is determined using validated assessment tools, including assessments of the kind and localization of cancer, treatment strategy and some individual and biological characteristics (age, comorbidities, platelet counts, etc.) $[11,61,70]$. Some assessment tools have also been validated for H\&N cancer surgery, such as the Caprini risk assessment model [58,62,71]. In cases of major surgery for cancer, which is almost always the case for $\mathrm{H} \& \mathrm{~N}$ cancer, the ASCO clearly recommends thromboprophylaxis; the thromboprophylaxis must be started before surgery and be continued for 7-10 days after surgery. The use of LMWH is recommended, and the hemorrhagic risk must be evaluated before starting treatment. H\&N surgeons and ENT societies recommend mechanical prophylaxis for VTE for all patients with VTE risk. The same societies also recommend pharmacological thromboprophylaxis by LMWH. Pharmacological thromboprophylaxis is not systematically provided by certain teams without the occurrence of additional VTE events following H\&N cancer surgery $[44,58,62,72,73]$. This issue is addressed in the previous paragraph.

\section{Biological/Fundamental Research Contributions}

\subsection{Background}

The existence of a biological interrelation between cancer and the hemostatic system is widely recognized for most cancers, especially for colon, pancreas, ovarian and lung cancer. Different biological mechanisms have been shown to explain thrombosis associated with cancer: expression of hemostatic proteins [74] or adhesion platelet molecules by tumor cells [75], production of procoagulant microparticles (MP) by tumor and/or host cells [76], inflammation [77], and the presence of other molecules such as some proangiogenic factors (VEGF, $\beta$ TGF) [78]. 
These mechanisms have been less studied for H\&N cancer, most likely because the associated clinical thrombosis risk is considered low; however, existing data seem to show that a similar interrelation might also exist for this kind of cancer. As stated above, thrombosis risk is dependent on the histological features of the tumor, which is why we limited our review to H\&N SCC, the more representative kind of tumor in $\mathrm{H} \& \mathrm{~N}$ cancer.

\subsection{HEN SCC and the Proteins Related to Aggregation and Coagulation Mechanisms}

\subsubsection{Tissue Factor/Tissue Factor Pathway Inhibitor (and Thrombin)}

Tissue factor (TF), also called factor III or thromboplastin, is a transmembrane glycoprotein that plays a central role in blood clotting. Physiologically, TF triggers blood coagulation by binding factor VII and converting factor VII to its active form, VIIa. The TF/VIIa complex activates factor X and ultimately facilitates thrombin and fibrin production. TF is normally present in connective tissue but not in circulating blood. TF can be expressed by endothelial cells, monocytes and neutrophils after induction [79]. Tissue factor pathway inhibitor (TFPI) is a plasma serine protease inhibitor, which is a natural powerful inhibitor of the factor $\mathrm{X}$ and TF/VIIa complex. TFPI is normally synthetized by vascular endothelial cells. TFPI could also be expressed by fibroblasts, smooth muscle cells and macrophages [80]. The thrombotic profile of a cell or a tissue is in fact related to the TFPI/TF balance. In addition, TF and TFPI are also involved in maintaining pathological conditions, especially in cancer [81]. It has been showed that TF is involved in cancer angiogenesis, invasion, growth, metastasis and cancer-associated thrombosis by triggering blood clotting. The ectopic expression of TF has been detected in several cancers, including gastric cancer [82], pancreatic cancer [83] and breast cancer [84]. The inappropriate expression of TF in tumor cells is due to the activation of the pro-oncogene EGFR, which enhances TF expression [85]. This relationship seems to also apply for H\&N SCC; the immunofluorescence study by Wojtsukiewicz et al. showed strong expression of TF on cells from human laryngeal SCC [86]. Christensen et al. found the same conclusion with cells from human oral squamous cell carcinoma (OSCC) using the same imaging method [87]. Chang et al. also found elevated TF expression in SAS cells, a human cell line of OSCC, by increasing mRNA coding for TF. Moreover, their study showed that SAS cells could induce platelet aggregation in vitro (also called TCIPA, or tumor-cell induced platelet aggregation) by a mechanism that directly involves TF [88]. Using flow cytometry, Welsh et al. demonstrated that several H\&N SCC cell lines expressed TF at a more elevated level than other cell lines reputed to have high-level TF expression. The authors have also shown that the level of TF expression was directly correlated with the procoagulant cell capacity in vitro [89]. Another procoagulant mechanism involving TF was highlighted by Adesanya et al. They showed that the in vitro production of specific microvesicles from H\&N SCC cell lines could facilitate TF expression by endothelial cells by inducing blood clotting and platelet aggregation [90]. This mechanism is certainly implicated in the strong expression of TF in H\&N SCC pericarcinomatous tissue, as shown by Wang et al. in their immunohistological study conducted on human laryngeal SCC [91].

Even if it had been studied less, TFPI would have a role in cancer. The expression of TFPI has also been observed in some tumors and cancer cell lines, such as those from breast, pancreatic and colorectal cancer [81,92]. In contrast to TF, TFPI may have a beneficial effect on cancer cells and decreases the invasive potential of the disease, especially by inhibiting serine proteases such as matrix metalloproteases and plasmins involved in determining the aggressiveness of cancer [93]. Wojtukiewicz et al. showed that cells from human laryngeal SCC did not express high levels TFPI [86]; moreover, they showed in another study that the TFPI expression level in laryngeal SCC tissue was decreased compared to that in normal laryngeal tissue [94]. TFPI was recently recognized as a tumor-suppressor gene in melanoma [95], and it has even been used as a gene therapy target to successfully treat laryngeal squamous cell carcinoma in mice [96]. 
Taken together, these facts suggest that the TF/TFPI balance is clearly in benefit of TF and that H\&N SCC should be associated with a high risk of VTE. Practically, we did not find this result in our clinical review about H\&N SCC and its associated VTE thrombosis risk, which was rather considered very low. The high expression of TF seems to be insufficient to increase the thrombosis risk associated with H\&N cancer, as has also been shown for other cancer localization [97]. High TF expression does, however, explain why prothrombin and fibrin are present in tumor and peritumor sites of HNSCC cancer; prothrombin and fibrin are indicators of local activation of blood coagulation [98]. This might also explain the frequency of venous thrombosis in the areas adjacent to H\&N SCC (internal jugular vein thrombosis); the thrombosis may occur by platelet activation/aggregation due to direct contact with tumor cells or by endothelial cells activated by tumor cell microvesicles $[99,100]$.

\subsubsection{The Fibrinolysis and Plasmin-Plasminogen System}

The blood fibrinolytic system relies on an inactive proenzyme, plasminogen, that can be converted to an active form, plasmin. Plasmin is a serine protease that degrades the final product of the coagulation system, fibrin, which is directly implicated in VTE. Under normal conditions, the balance between fibrinolysis and the coagulation system results in an increase or decrease of each, which has consequences on the risk of VTE. Thus, the diminution of the fibrinolytic system activities would increase the VTE risk [101]. Plasminogen is synthetized by hepatocytes and is widely present in the blood circulation under normal conditions. Plasminogen activation consists of two other serine proteases, tissue plasminogen activator (tPA) and urokinase plasminogen activator (uPA), along with its cellular receptor (urokinase plasminogen activator receptor-uPAR). tPA is synthetized by endothelial cells and is activated by fibrin. uPA is synthetized by many cell types, especially kidney cells, and is activated by factor XII. The activity of uPA is enhanced when UPA is fixed to its receptor uPAR, which is expressed by many different cells. Plasminogen activator inhibitor (PAI) is the most important inhibitor of the fibrinolytic system and blocks the activation of tPA and uPA. The serine protease of PAI exists in two forms: one constitutive form, PAI-1, and one form only present during pregnancy and some hematological diseases, PAI-2. The two other inhibitors that exist are $\alpha$-2-antiplasmin and thrombin-activated fibrinolysis inhibitor (TAFI). These inhibitors directly inhibit fibrin degradation by plasmin.

Kosugi et al. were the first to show modifications of the fibrinolysis system in patients with H\&N SCC based on blood examinations. They also suggested the down-regulation of the fibrinolysis system which might cause an elevated VTE risk [102]. Later, Jagielska et al. conducted a study based on the blood examination of 32 patients with advanced H\&N SCC and reached the same conclusion; moreover, they showed a significant elevation of levels of PAI-1 in the blood, which might explain the down regulation of the fibrinolysis system and the potential increase in the VTE risk [103]. Hundsdorfer and colleagues, using enzyme-linked immunosorbent assays (ELISA), analyzed OSCC in 79 patients to compare uPA and PAI-1 levels between tumor tissue and normal tissue. They found a global elevation of both proteases, without a true superiority of either the activator or inhibitor of plasminogen [104]. Serpa et al. also found elevated uPA levels in a similar study conducted on human tongue SCC and showed that SCC cells had an elevation in the expression of uPAR [105]. Baker et al. conducted a more complete study and showed an elevation in UPA, UPAR, PAI-1 and PAI-2 expression in human OSCC tumor tissue. They also showed a correlation between protease levels and the aggressiveness of the tumor [106]. This relationship is not surprising because the role of plasmin (matrix degradation, metalloprotease activation) has been clearly shown in facilitating the progression and metastasis processes of H\&N SCC $[107,108]$. We did not find any studies about TAFI expression and H\&N cancer; however, it has been shown that some polymorphisms of the TAFI gene can have a protective effect for OSCC [109].

In summary, despite the trend of fibrinolysis downregulation that seemingly exists in H\&N cancer, which would enhance the incidence of associated thrombosis, it is difficult to definitively define this 
phenomenon. In fact, there could be a global elevation of plasminogen activator (tPA, uPA) and inhibitor (PAI) levels, which can balance with each other without consequence on thrombosis risk.

\subsubsection{Others Coagulation/Aggregation Factors}

Thromboxane A2 and Prostacyclin

Thromboxane A2 (TXA2) and prostacyclin (PGI2) are two products formed from arachidonic acid by cyclooxygenase. TXA2 is an activator of platelet aggregation, and its action is due to the enhanced concentration of Ca2+ in platelets following TXA2 binding on its own receptor. PGI2 has the opposite effect, with a strong inhibition of platelet aggregation through the stimulation of adenylate cyclase that then leads to an increase in cyclic AMP and a diminution of $\mathrm{Ca} 2+$ concentration in the platelets. An elevation of TXA2 or diminution of PGI2 levels would enhance thrombosis risk, and such a mechanism could be involved in thrombosis associated with colon cancer $[110,111]$.

Using radioimmunoassays of human laryngeal SCC, Pinto et al. showed in their study that there was a significant elevation of TXA2 production in tumor and peritumor tissues compared with in normal tissue [112]. Using the same technical method, Slotman found an elevated plasma TXA2 concentration in patients with H\&N SCC. The author also found that none of these patients had elevated plasma PGI2 concentrations [113]. Camacho et al. found the same results in their study using mRNA PGI2 pathway enzyme analysis conducted on human H\&N SCC; moreover, they showed an association between a decrease in PGI2 production and poor prognosis of the disease [114]. In brief, the metabolism of TXA2 and PGI2 might be affected in H\&N cancer patients, with a balance in favor of TXA2, which could be responsible for an increase in thrombosis risk.

\section{Podoplanin}

Podoplanin is a mucin-type transmembrane glycoprotein that is specifically expressed in lymphatic endothelial cells but not in normal blood endothelial cells. Podoplanin has the ability to induce direct platelet activation via the platelet-receptor CLEC-2, and the role of podoplanin in cancer-associated thrombosis has been mainly reported for brain tumors [115]. However, the overexpression of podoplanin and its potential role in cancer-associated thrombosis has also been shown in other kinds of tumors, such as lung [116] or breast [117]. H\&N SCC is also be associated with a high expression of podoplanin. Yuan et al. showed an overexpression of podoplanin in human oral and hypopharyngeal SCC tissue in their immunohistological studies [118]. Martin-Villar et al. found the same conclusions in their genetic and immunohistological study of OSCC using human genetic material transfected into mice. Moreover, they highlighted a potential role of podoplanin expression in OSCC and platelet activation [119]. All of these studies also showed a strong correlation between cancer prognosis and podoplanin, especially its existence in cervical lymph nodes [120]. Thus, aggressive H\&N cancer with high podoplanin expression can be associated with an elevated associated thrombosis risk.

\section{Von Willebrand Factor}

Von Willebrand factor (vWF) is a plasma glycoprotein synthesized in endothelial cells and megakaryocytes. vWF promotes the adhesion of platelets to subendothelial connective tissue and to endothelial cells in cases of blood vessel damage. vWF is also a carrier protein for factor VIII. Some studies have demonstrated increased vWF plasma levels in cancer cells with a potential implication in thrombosis-associated risk [121,122]. Sweeney and colleagues first highlighted the elevation of vWF plasma levels in patients with extended H\&N SCC [123]. Paczuski et al. conducted a similar study in patients with laryngeal SCC and concluded that patients with extended cancer or with metastatic lymph nodes had a high plasmatic level of vWF [124]. As in the Sweeney study, the authors did not find any significant difference in vWF plasma levels between patients with small or moderate cancer and patients without disease. Similar to podoplanin levels, vWF plasmatic levels are enhanced with 
the aggressiveness and size of H\&N tumors, and then associated with a potential elevation of the thrombosis risk.

Thrombomodulin

Thrombomodulin (TM) is a glycoprotein that was originally identified on the vascular endothelium and characterized as a major natural endothelial anticoagulant. TM plays a role as a cofactor for thrombin binding and mediates protein $\mathrm{C}$ activation and inhibits thrombin activity. TM is physiologically expressed on various cells, such as megakaryocytes, platelets, monocytes, macrophages, and different squamous and mesothelial cells [125]. It has been shown that TM is also expressed on various cancers such as lung or pancreas cancer $[126,127]$ and that elevated TM expression is associated with a decrease in the aggressiveness of the tumor. The same findings have been shown for H\&N cancer. Tabata et al. showed the expression of TM in human OSCC tissue in their study based on immunohistological examinations. Moreover, they showed a relationship between TM level, the risk of lymph node metastasis and the survival rate. A high level of TM might be associated with a better prognosis [128]. Gaspar et al. found the same conclusions in their study about human laryngeal and pharyngeal SCC [129]. These findings suggest that aggressive tumors with low TM levels are associated with a high risk of associated thrombosis.

Our research has also explored coagulation inhibitors (antithrombin, heparin cofactor II, S protein, etc.) as well as other coagulation/aggregation related proteins, especially platelet adhesion molecules (platelet integrin $\alpha 2 \beta 3$, p-selectin, cadherin, etc.), but has not found any convincing results. Taking all these separate pieces of information together, we believe that biological findings would be quite in favor of an elevated risk of thrombosis associated with $\mathrm{H} \& \mathrm{~N}$ cancer.

\subsection{HEN SCC and Microparticles}

Microparticles (MPs) are small membrane vesicles ranging from 0.1 to $1 \mu \mathrm{m}$ in size and are formed by budding from the plasma membrane. MPs are released following cell activation, injury or apoptosis. Circulating MPs play important roles in physiological and pathological conditions, especially in cancer-associated thrombosis [130]. MPs can be released directly from cancer cells but also by other cell types (platelets, endothelial cells, neutrophils, etc.) after being induced by tumor cells. The procoagulant activity of MPs could not only be due to TF membrane expression but also to the presence of phosphatidylserine, which provides a negatively charged surface to support the assembly of coagulation complexes. Even though we did not find any studies that specifically highlighted the plasmatic presence of TF-bearing MP from H\&N SCC cells, this presence is suggested by some studies; this occurrence is easy to imagine since we showed that H\&N SCC cells had high TF expression levels and H\&N SCC patients have facial areas with rich vascularization.

Ren et al. showed elevated levels of circulating platelet-derived MPs in 63 patients with OSCC compared to in healthy volunteers and compared to in patients with infected benign cysts of the jaw. The authors also showed an increased level of total circulating MPs in patients with OSCC. Moreover, they highlighted that circulating MPs from OSCC patient plasma had procoagulant activity and that the circulating MPs reduced coagulation time of normal plasma vitro when they were added. However, no modifications of activated thromboplastin time (APTT) and prothrombin time (PT) was found in OSCC patients [131].

As discussed above, Adesanya et al. have shown that H\&N SCC cells could produce in vitro microvesicles with TF-dependent procoagulant activity. The authors also showed that H\&N SCC-derived microvesicles could activate umbilical vein endothelial cells with TF surface expression and a procoagulant profile [90]. Sierko et al. has shown a high level of plasma TF-bearing endothelial MPs in their study conducted in 16 patients with H\&N SCC treated by radiotherapy. However, they did not find any abnormalities in the hemostatic system in those patients [132].

These findings about MPs support the arguments for an elevated thrombosis risk associated with H\&N SCC, but an effective MP-dependent thrombosis risk is supported by the balance between 
pro and anticoagulant MPs [133]. However, we did not find any reports about anticoagulant MPs in $\mathrm{H} \& \mathrm{~N}$ cancer.

\subsection{HEN SCC, Inflammation and Angiogenesis}

Cancer is subject to an inflammatory response that is responsible for a procoagulant state. On one hand, this is due to the direct modulation of platelet function (activation) and, on the other hand, to procoagulant cytokine secretion [134]. The most well-defined pro-inflammatory cytokines that have been shown to exert pro-thrombotic effects are tumor necrosis factor alpha (TNF $\alpha$ ) and interleukin-1 (IL-1). TNF $\alpha$ and IL-1 can induce the expression of TF and von Willebrand factor (vWF) on vascular endothelial cells. It has also been shown that interleukin-6 (IL-6) has a pro-thrombotic effect by expressing TF, vWF and factor VIII but also by downregulating the expression of antithrombotic molecules such as antithrombin III, protein $S$ and thrombomodulin $[4,135]$. Similar to other cancers, H\&N SCC is subject to systemic inflammation responses and secretions of cytokines by immune cells. Gallo et al. showed a significantly higher potential for TNF $\alpha$ secretion by monocytes from patients with OSCC than from control patients without tumors [136]. Parks et al. evaluated that the proper production of $\mathrm{TNF} \alpha$ by tumor cells in vitro using cells issued from tumors of 9 patients with H\&N SCC [137]. In vivo TNF $\alpha$ secretion by H\&N SCC cells was confirmed by Nakano et al. in their study based on immunohistological analysis and more recently by Scheff et al. in their study conducted in mice $[138,139]$. The same findings are also applicable for IL-1 and IL-6, and Gallo et al. and Tsai et al. showed an increase in vitro in interleukin secretion by monocytes from patients with H\&N SCC $[140,141]$. Thomas et al. showed that murine OSCC cell lines were able to directly express IL-1 and IL-6 in vitro [142]. Wang et al. confirmed these findings in vivo in humans and showed that this secretion contributed to a high level of IL-1 and IL-6 in the circulating blood and in the tumor peri-environment [143].

Other cytokines, especially those implicated in angiogenesis associated with tumor development, are known to have a prothrombotic effect. Vascular endothelial growth factor (VEGF) is a potent angiogenic cytokine implicated in tumor vasculogenesis. It has been shown that VEGF has a procoagulant effect by inducing TF expression by macrophages $[78,144]$. Chen et al. showed that OSCC cell lines freshly cultured from human tumors are able to secrete VEGF in vitro [145]. Johnston et al. and Eisma et al. demonstrated that high VEGF expression existed in OSCC tumors and in OSCC tumor environments in vivo in humans [146,147]. Granulocyte-macrophage colony-stimulating factor (GM-CSF) is a cellular growing factor shown to have potential procoagulant activity due to its stimulation of vWF production [148]. The expression of GM-CSF by tumor cells and its presence in the tumor environment of H\&N SCC has also been shown [142,149]. Taken together, these findings suggest that there is elevated production/secretion of procoagulant cytokines in H\&N cancer, which is again supports the argument for an effective associated thrombosis risk.

\section{H\&N SCC, Thrombosis and Cancer Progression}

As we have shown, it seems that a local prothrombotic area associated with H\&N cancer exists, which can lead to platelet activation/aggregation and thrombus generation in the tumor environment. Platelets are a large reservoir of biomolecules that are stored in granules. Upon activation, especially in tumor cells, platelets can release their granule contents. Through this action, it has been shown that platelets could play several roles in the progression of malignancies [150]. Platelet alpha granules are full of growth and angiogenic factors, such as vascular epithelial growth factor (VEGF), epidermal growth factor (EGF), platelet-derived growth factor (PDGF) and transforming growth factor (TGF $\beta$ ). VEGF, as mentioned above, is a growth factor involved in the induction of vasculogenesis and angiogenesis, which are both needed for tumor growth [151]. The angiogenic role of VEGF has been demonstrated in various types of cancers, and the potential role of VEGF in the progression of OSCC has also been reported [152]. The potential effect of VEGF on bone invasion by OSCC cells has also been shown [153]. EGF is a powerful mitogen growth factor that has an important effect on OSCC cells that 
overexpress the EGF receptor. Platelet EGF promotes invasion, migration, and epithelial mesenchymal transition in OSCC cells [154]. These roles are why anti-EGF receptor therapy can work as an OSCC treatment [155]. PDGF are peptides that signal through cell-surface receptor tyrosine kinases (PDGFRs) and activate various cellular functions, such as proliferation, growth and differentiation. The effect of PDGF on different kinds of cancers has been shown in breast and some digestive cancers. The effect of PDGF on OSCC cells has also been reported, especially for tongue SCC $[156,157]$. The role of TGF $\beta$, another growth factor, is far less clear. Indeed, according to the stage of cancer, TGF can promote or inhibit tumor progression. This effect has been shown for squamous cell carcinoma, including H\&N SCC [158]. In short, with the possible exception of TGF $\beta$, platelet secretion products can have a positive effect on tumor progression and invasion. Moreover, it should be noted that the platelet and fibrinogen coat around the tumor might protect the tumor against the cytotoxic activity of natural killer cells, as Palumbo et al. showed in their study about breast cancer in mice [159]. In addition, platelet aggregation around cancer cells can also be useful in protecting cancer cells against high shear stress in the bloodstream [160].

Nonetheless, even if there are no reports yet, one might believe that the very low rate of VTE associated with H\&N cancer would reflect the scarcity of distant metastases in this kind of tumor; in contrast, certain tumors that have a high thrombosis risk also have a high risk of metastasis, such as pancreatic cancer [161].

\section{Conclusions}

The physiopathogenesis of thrombosis associated with H\&N cancer is complex and involves both clinical and biological factors. Our clinical review highlighted that H\&N cancer may be associated with a very low rate of VTE, and most of time, H\&N cancer was evaluated to have the lowest risk of all studied cancer localizations, and in some studies, the risk was even less than that of hospitalized patients without malignancies. However, we also reported that, notably, no strong factual evidence exists due to the presence of recurrent biases and the fact that some studies had contradictory results. Our review reported that biologically, H\&N cancer is associated with most mechanisms found in cancers associated with a high thrombosis risk, including the following: modified thrombosis and fibrinolysis mechanisms, expression of procoagulant proteins, liberation of procoagulant MPs, and production of procoagulant cytokines. Taken together, these facts lead to a paradoxical conclusion: $\mathrm{H} \& \mathrm{~N}$ cancer has the biological features of a cancer with a high risk of thrombosis but has a clinical thrombosis risk that is estimated to be very low. We propose the following hypotheses to explain this contradiction (Figure 1):

There are flaws in many of the clinical studies that have assessed the thrombosis risk associated with H\&N cancer, and many studies might underestimate the risk.

$H \& N$ tumors show similar features to tumors with a high thrombosis risk, but H\&N tumors only show local procoagulant abilities without any effects on distant VTE (phlebitis and pulmonary embolism).

Undiscovered mechanism(s) may exist, which could balance the potential thrombotic power of H\&N tumors. We consider this last hypothesis to be the least unlikely.

The use of biological tests directly based on the molecular features of coagulation might be useful in validating these hypotheses and in determining the real thrombosis risk associated with H\&N cancer. These tests would be an assessment of the thromboelastographic profile; the utility of which has been reported for some cancers, including those of the digestive tract and liver, and multiple myeloma [162-164]. These tests can also study thrombosis in vivo, especially in real time by using intravital microscopy procedures [161]. 

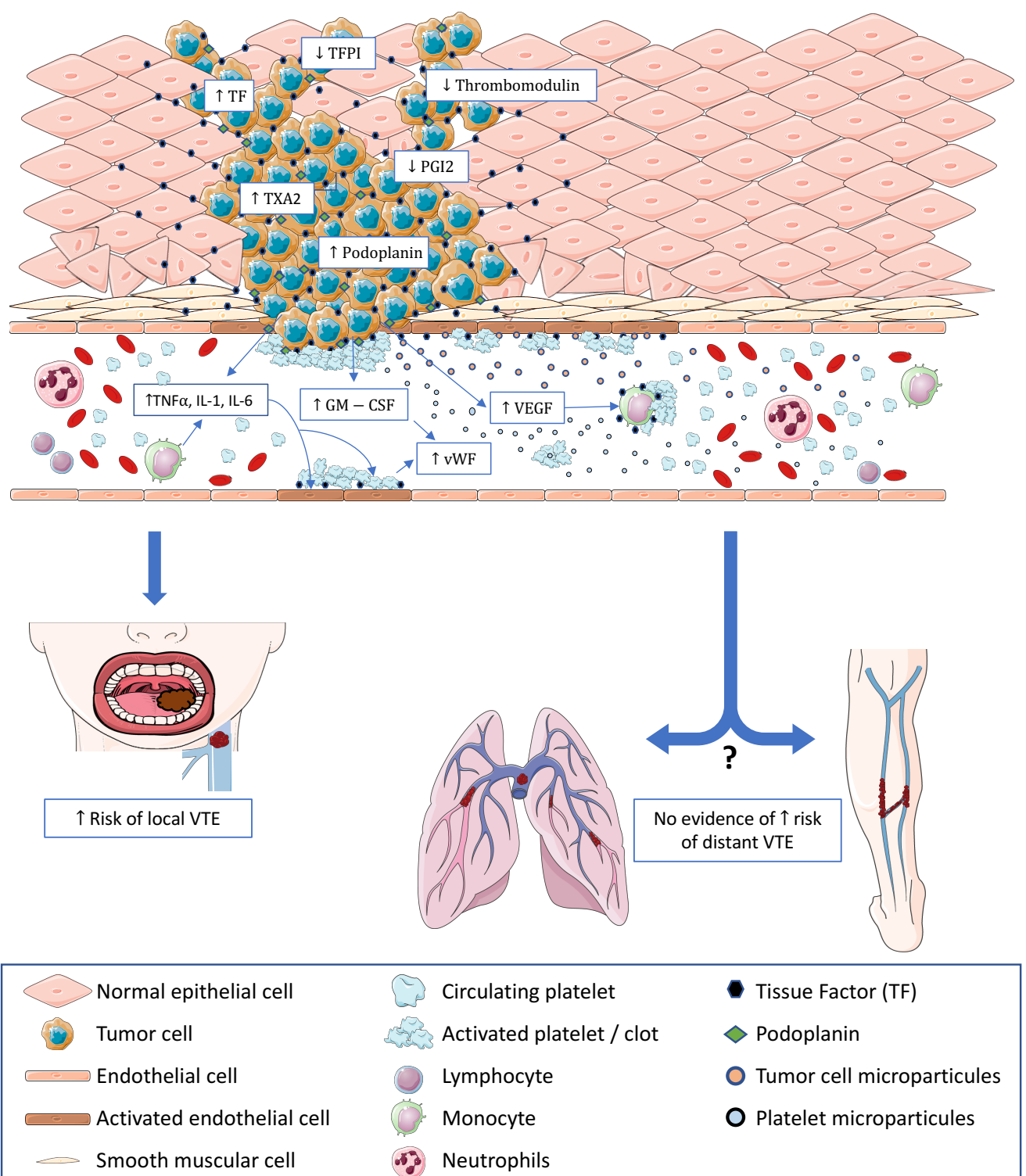

Circulating platelet
Activated platelet / clot
Lymphocyte
Monocyte
Neutrophils

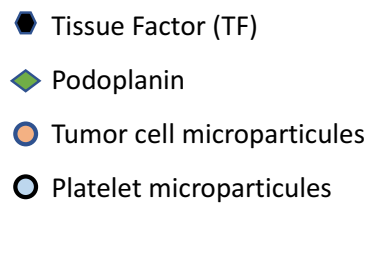

Figure 1. Potential mechanisms involved in thrombosis associated with $H \& N$ cancer and their consequences on the local and at-distance VTE risk. Some procoagulant molecules are overexpressed by tumor cells and in the tumor microenvironment including TF, podoplanin, and TXA2. In contrast, there is a downregulation of anticoagulant molecules, such as PGI2, TFPI and TM. Procoagulant MPs from tumor cells and from platelets are released. Procoagulant cytokines such as TNF $\alpha$, IL1, and IL6 are secreted by immune cells or directly by tumor cells. Platelet activation is essentially supported by TF expression on tumor cells, activated endothelial cells, monocytes and potentially MPs. All these described mechanisms seem to be involved in elevating the risk of VTE in the areas adjacent to the tumor and might be in accordance with the clinical findings. However, it would be extremely difficult to draw conclusions about the influence of these mechanisms on the distant risk of VTE since our clinical review showed a very low incidence of pulmonary embolism and phlebitis associated with $\mathrm{H} \& \mathrm{~N}$ cancer.

Author Contributions: All listed authors wrote the MS and prepared figures.

Conflicts of Interest: The authors declare no conflict of interest. 


\section{Abbreviations}

$\begin{array}{ll}\text { VTE } & \text { venous thromboembolism } \\ \text { H\&N } & \text { head and neck } \\ \text { SCC } & \text { squamous cell carcinoma } \\ \text { MPs } & \text { microparticules } \\ \text { TF } & \text { tissue factor } \\ \text { TFPI } & \text { tissue factor pathway inhibitor } \\ \text { OSCC } & \text { oral squamous cell carcinoma } \\ \text { ASCO } & \text { American Society of Clinical Oncology } \\ \text { LMWH } & \text { low molecular weight heparin } \\ \text { VKA } & \text { vitamin K antagonist } \\ \text { tPA } & \text { tissue plasminogen activators } \\ \text { uPA } & \text { urokinase plasminogen activators } \\ \text { PAI } & \text { plasminogen activator inhibitor } \\ \text { TAFI } & \text { thrombin activated fibrinolysis inhibitor } \\ \text { ELISA } & \text { enzyme-linked immunosorbent assays } \\ \text { TXA2 } & \text { thromboxane A2 } \\ \text { PGI2 } & \text { prostacyclin } \\ \text { vWF } & \text { von Willebrand factor } \\ \text { TM } & \text { thrombomodulin } \\ \text { TNF } & \text { tumor necrosis factor } \\ \text { IL } & \text { interleukin } \\ \text { VEGF } & \text { vascular endothelial growth factor } \\ \text { GM-CSF } & \text { granulocyte-macrophage colony-stimulating factor } \\ \text { EGF } & \text { epidermal growth factor } \\ \text { PDGF } & \text { platelet-derived growth factor } \\ \text { TGF } \beta & \text { transforming growth factor } \\ & \end{array}$

\section{References}

1. Trousseau, A. Plegmasia alba dolens. In Lectures on Clinical Medicine, Delivered at the Hotel-Dieu, Paris; New Sydenham Society: London, UK, 1872; pp. 281-295.

2. Bouillaud, S. De l'Obliteration des veines et de son influence sur la formation des hydropisies partielles: consideration sur la hydropisies passive et general. Arch. Gen. Med. 1823, 1, 188-204.

3. Blom, J.W.; Doggen, C.J.M.; Osanto, S.; Rosendaal, F.R. Malignancies, prothrombotic mutations, and the risk of venous thrombosis. JAMA 2005, 293, 715-722. [CrossRef] [PubMed]

4. Falanga, A.; Russo, L.; Milesi, V.; Vignoli, A. Mechanisms and risk factors of thrombosis in cancer. Crit. Rev. Oncol. Hematol. 2017, 118, 79-83. [CrossRef] [PubMed]

5. Falanga, A.; Schieppati, F.; Russo, D. Cancer Tissue Procoagulant Mechanisms and the Hypercoagulable State of Patients with Cancer. Semin. Thromb. Hemost. 2015, 41, 756-764. [PubMed]

6. Date, K.; Hall, J.; Greenman, J.; Maraveyas, A.; Madden, L.A. Tumour and microparticle tissue factor expression and cancer thrombosis. Thromb. Res. 2013, 131, 109-115. [CrossRef] [PubMed]

7. Falanga, A.; Panova-Noeva, M.; Russo, L. Procoagulant mechanisms in tumour cells. Best Pract. Res. Clin. Haematol. 2009, 22, 49-60. [CrossRef]

8. Campello, E.; Spiezia, L.; Radu, C.M.; Bulato, C.; Castelli, M.; Gavasso, S.; Simioni, P. Endothelial, platelet, and tissue factor-bearing microparticles in cancer patients with and without venous thromboembolism. Thromb. Res. 2011, 127, 473-477. [CrossRef]

9. Königsbrügge, O.; Pabinger, I.; Ay, C. Risk factors for venous thromboembolism in cancer: novel findings from the Vienna Cancer and Thrombosis Study (CATS). Thromb. Res. 2014, 133, S39-S43. [CrossRef]

10. Khorana, A.A. Venous thromboembolism and prognosis in cancer. Thromb. Res. 2010, 125, 490-493. [CrossRef] 
11. Farge, D.; Bounameaux, H.; Brenner, B.; Cajfinger, F.; Debourdeau, P.; Khorana, A.A.; Pabinger, I.; Solymoss, S.; Douketis, J.; Kakkar, A. International clinical practice guidelines including guidance for direct oral anticoagulants in the treatment and prophylaxis of venous thromboembolism in patients with cancer. Lancet Oncol. 2016, 17, e452-e466. [CrossRef]

12. Kahale, L.A.; Hakoum, M.B.; Tsolakian, I.G.; Matar, C.F.; Terrenato, I.; Sperati, F.; Barba, M.; Yosuico, V.E.; Schünemann, H.; Akl, E.A. Anticoagulation for the long-term treatment of venous thromboembolism in people with cancer. Cochrane Database Syst. Rev. 2018, 6, CD006650. [CrossRef] [PubMed]

13. Akl, E.A.; Labedi, N.; Barba, M.; Terrenato, I.; Sperati, F.; Muti, P.; Schünemann, H. Anticoagulation for the long-term treatment of venous thromboembolism in patients with cancer. Cochrane Database Syst. Rev. 2011, 6, CD006650.

14. Ferlay, J.; Soerjomataram, I.; Dikshit, R.; Eser, S.; Mathers, C.; Rebelo, M.; Parkin, D.M.; Forman, D.; Bray, F. Cancer incidence and mortality worldwide: Sources, methods and major patterns in GLOBOCAN 2012. Int. J. Cancer 2015, 136, E359-E386. [CrossRef] [PubMed]

15. Siegel, R.L.; Miller, K.D.; Jemal, A. Cancer statistics, 2018. CA Cancer J. Clin. 2018, 68, 7-30. [CrossRef] [PubMed]

16. Pan, R.; Zhu, M.; Yu, C.; Lv, J.; Guo, Y.; Bian, Z.; Yang, L.; Chen, Y.; Hu, Z.; Chen, Z.; et al. Cancer incidence and mortality: A cohort study in China, 2008-2013. Int. J. Cancer 2017, 141, 1315-1323. [CrossRef]

17. Gupta, B.; Johnson, N.W.; Kumar, N. Global Epidemiology of Head and Neck Cancers: A Continuing Challenge. Oncology 2016, 91, 13-23. [CrossRef]

18. Weatherspoon, D.J.; Chattopadhyay, A.; Boroumand, S.; Garcia, I. Oral cavity and oropharyngeal cancer incidence trends and disparities in the United States: 2000-2010. Cancer Epidemiol. 2015, 39, 497-504. [CrossRef]

19. Jiang, S.; Dong, Y. Human papillomavirus and oral squamous cell carcinoma: A review of HPV-positive oral squamous cell carcinoma and possible strategies for future. Curr. Probl. Cancer 2017, 41, 323-327. [CrossRef]

20. Sørensen, H.T.; Mellemkjaer, L.; Steffensen, F.H.; Olsen, J.H.; Nielsen, G.L. The risk of a diagnosis of cancer after primary deep venous thrombosis or pulmonary embolism. N. Engl. J. Med. 1998, 338, 1169-1173. [CrossRef]

21. Baron, J.A.; Gridley, G.; Weiderpass, E.; Nyrén, O.; Linet, M. Venous thromboembolism and cancer. Lancet Lond. Engl. 1998, 351, 1077-1080. [CrossRef]

22. Paneesha, S.; McManus, A.; Arya, R.; Scriven, N.; Farren, T.; Nokes, T.; Bacon, S.; Nieland, A.; Cooper, D.; Smith, H.; et al. Frequency, demographics and risk (according to tumour type or site) of cancer-associated thrombosis among patients seen at outpatient DVT clinics. Thromb. Haemost. 2010, 103, 338-343. [CrossRef] [PubMed]

23. Prandoni, P.; Lensing, A.W.; Büller, H.R.; Cogo, A.; Prins, M.H.; Cattelan, A.M.; Cuppini, S.; Noventa, F.; ten Cate, J.W. Deep-vein thrombosis and the incidence of subsequent symptomatic cancer. N. Engl. J. Med. 1992, 327, 1128-1133. [CrossRef] [PubMed]

24. Piccioli, A.; Lensing, A.W.A.; Prins, M.H.; Falanga, A.; Scannapieco, G.L.; Ieran, M.; Cigolini, M.; Ambrosio, G.B.; Monreal, M.; Girolami, A.; et al. Extensive screening for occult malignant disease in idiopathic venous thromboembolism: a prospective randomized clinical trial. J. Thromb. Haemost. JTH 2004, 2, 884-889. [CrossRef] [PubMed]

25. Trujillo-Santos, J.; Prandoni, P.; Rivron-Guillot, K.; Román, P.; Sánchez, R.; Tiberio, G.; Monreal, M.; RIETE Investigators. Clinical outcome in patients with venous thromboembolism and hidden cancer: findings from the RIETE Registry. J. Thromb. Haemost. JTH 2008, 6, 251-255. [CrossRef] [PubMed]

26. Sørensen, H.T.; Sværke, C.; Farkas, D.K.; Christiansen, C.F.; Pedersen, L.; Lash, T.L.; Prandoni, P.; Baron, J.A. Superficial and deep venous thrombosis, pulmonary embolism and subsequent risk of cancer. Eur. J. Cancer Oxf. Engl. 1990 2012, 48, 586-593.

27. Petterson, T.M.; Marks, R.S.; Ashrani, A.A.; Bailey, K.R.; Heit, J.A. Risk of site-specific cancer in incident venous thromboembolism: a population-based study. Thromb. Res. 2015, 135, 472-478. [CrossRef] [PubMed]

28. Robin, P.; Le Roux, P.-Y.; Planquette, B.; Accassat, S.; Roy, P.-M.; Couturaud, F.; Ghazzar, N.; Prevot-Bitot, N.; Couturier, O.; Delluc, A.; et al. Limited screening with versus without (18)F-fluorodeoxyglucose PET/CT for occult malignancy in unprovoked venous thromboembolism: an open-label randomised controlled trial. Lancet Oncol. 2016, 17, 193-199. [CrossRef] 
29. Sun, L.-M.; Chung, W.-S.; Lin, C.-L.; Liang, J.-A.; Kao, C.-H. Unprovoked venous thromboembolism and subsequent cancer risk: a population-based cohort study. J. Thromb. Haemost. JTH 2016, 14, 495-503. [CrossRef]

30. Sandén, P.; Svensson, P.J.; Själander, A. Venous thromboembolism and cancer risk. J. Thromb. Thrombolysis 2017, 43, 68-73. [CrossRef]

31. Jara-Palomares, L.; Otero, R.; Jimenez, D.; Carrier, M.; Tzoran, I.; Brenner, B.; Margeli, M.; Praena-Fernandez, J.M.; Grandone, E.; Monreal, M.; et al. Development of a Risk Prediction Score for Occult Cancer in Patients With VTE. Chest 2017, 151, 564-571. [CrossRef]

32. Delluc, A.; Ianotto, J.-C.; Tromeur, C.; De Moreuil, C.; Couturaud, F.; Lacut, K.; Le Moigne, E.; Louis, P.; Thereaux, J.; Metges, J.-P.; et al. Real-world incidence of cancer following a first unprovoked venous thrombosis: Results from the EPIGETBO study. Thromb. Res. 2018, 164, 79-84. [CrossRef] [PubMed]

33. Levitan, N.; Dowlati, A.; Remick, S.C.; Tahsildar, H.I.; Sivinski, L.D.; Beyth, R.; Rimm, A.A. Rates of initial and recurrent thromboembolic disease among patients with malignancy versus those without malignancy. Risk analysis using Medicare claims data. Medicine (Baltimore) 1999, 78, 285-291. [PubMed]

34. Sallah, S.; Wan, J.Y.; Nguyen, N.P. Venous thrombosis in patients with solid tumors: Determination of frequency and characteristics. Thromb. Haemost. 2002, 87, 575-579. [PubMed]

35. Khorana, A.A.; Francis, C.W.; Culakova, E.; Fisher, R.I.; Kuderer, N.M.; Lyman, G.H. Thromboembolism in hospitalized neutropenic cancer patients. J. Clin. Oncol. Off. J. Am. Soc. Clin. Oncol. 2006, 24, 484-490. [CrossRef] [PubMed]

36. Stein, P.D.; Beemath, A.; Meyers, F.A.; Skaf, E.; Sanchez, J.; Olson, R.E. Incidence of venous thromboembolism in patients hospitalized with cancer. Am. J. Med. 2006, 119, 60-68. [CrossRef] [PubMed]

37. Khorana, A.A.; Francis, C.W.; Culakova, E.; Kuderer, N.M.; Lyman, G.H. Frequency, risk factors, and trends for venous thromboembolism among hospitalized cancer patients. Cancer 2007, 110, 2339-2346. [CrossRef]

38. Walker, A.J.; Card, T.R.; West, J.; Crooks, C.; Grainge, M.J. Incidence of venous thromboembolism in patients with cancer-A cohort study using linked United Kingdom databases. Eur. J. Cancer Oxf. Engl. 1990 2013, 49, 1404-1413. [CrossRef] [PubMed]

39. Chew, T.-W.; Gau, C.-S.; Wen, Y.-W.; Shen, L.-J.; Mullins, C.D.; Hsiao, F.-Y. Epidemiology, clinical profile and treatment patterns of venous thromboembolism in cancer patients in Taiwan: a population-based study. BMC Cancer 2015, 15, 298. [CrossRef]

40. Innis, W.P.; Anderson, T.D. Deep venous thrombosis and pulmonary embolism in otolaryngologic patients. Am. J. Otolaryngol. 2009, 30, 230-233. [CrossRef]

41. Hennessey, P.; Semenov, Y.R.; Gourin, C.G. The effect of deep venous thrombosis on short-term outcomes and cost of care after head and neck cancer surgery. Laryngoscope 2012, 122, 2199-2204. [CrossRef]

42. Thai, L.; McCarn, K.; Stott, W.; Watts, T.; Wax, M.K.; Andersen, P.E.; Gross, N.D. Venous thromboembolism in patients with head and neck cancer after surgery. Head Neck 2013, 35, 4-9. [CrossRef] [PubMed]

43. Gavriel, H.; Thompson, E.; Kleid, S.; Chan, S.; Sizeland, A. Safety of thromboprophylaxis after oncologic head and neck surgery. Study of 1018 patients. Head Neck 2013, 35, 1410-1414. [CrossRef] [PubMed]

44. Clayburgh, D.R.; Stott, W.; Cordiero, T.; Park, R.; Detwiller, K.; Buniel, M.; Flint, P.; Schindler, J.; Andersen, P.; Wax, M.K.; et al. Prospective study of venous thromboembolism in patients with head and neck cancer after surgery. JAMA Otolaryngol.-Head Neck Surg. 2013, 139, 1143-1150. [CrossRef] [PubMed]

45. Lodders, J.N.; Parmar, S.; Stienen, N.L.M.; Martin, T.J.; Karagozoglu, K.H.; Heymans, M.W.; Forouzanfar, T. Incidence of symptomatic venous thromboembolism in oncological oral and maxillofacial operations: Retrospective analysis. Br. J. Oral Maxillofac. Surg. 2015, 53, 244-250. [CrossRef] [PubMed]

46. Ali, N.S.; Nawaz, A.; Junaid, M.; Kazi, M.; Akhtar, S. Venous Thromboembolism-Incidence of Deep Venous Thrombosis and Pulmonary Embolism in Patients with Head and Neck Cancer: A Tertiary Care Experience in Pakistan. Int. Arch. Otorhinolaryngol. 2015, 19, 200-204. [PubMed]

47. Kakei, Y.; Akashi, M.; Hasegawa, T.; Minamikawa, T.; Usami, S.; Komori, T. Incidence of Venous Thromboembolism After Oral Oncologic Surgery With Simultaneous Reconstruction. J. Oral Maxillofac. Surg. Off. J. Am. Assoc. Oral Maxillofac. Surg. 2016, 74, 212-217. [CrossRef] [PubMed]

48. Wang, Y.; Liu, J.; Yin, X.; Hu, J.; Kalfarentzos, E.; Zhang, C.; Xu, L. Venous thromboembolism after oral and maxillofacial oncologic surgery: Report and analysis of 14 cases in Chinese population. Med. Oral Patol. Oral Cirugia Bucal 2017, 22, e115-e121. [CrossRef] [PubMed] 
49. Thodiyil, P.A.; Kakkar, A.K. Variation in relative risk of venous thromboembolism in different cancers. Thromb. Haemost. 2002, 87, 1076-1077. [CrossRef]

50. Fuller, C.D.; Wang, S.J.; Thomas, C.R.; Hoffman, H.T.; Weber, R.S.; Rosenthal, D.I. Conditional survival in head and neck squamous cell carcinoma: results from the SEER dataset 1973-1998. Cancer 2007, 109, 1331-1343. [CrossRef]

51. Skarsgard, D.P.; Groome, P.A.; Mackillop, W.J.; Zhou, S.; Rothwell, D.; Dixon, P.F.; O'Sullivan, B.; Hall, S.F.; Holowaty, E.J. Cancers of the upper aerodigestive tract in Ontario, Canada, and the United States. Cancer 2000, 88, 1728-1738. [CrossRef]

52. Christensen, D.H.; Veres, K.; Ording, A.G.; Jørgensen, J.O.L.; Cannegieter, S.C.; Thomsen, R.W.; Sørensen, H.T. Risk of cancer in patients with thyroid disease and venous thromboembolism. Clin. Epidemiol. 2018, 10, 907-915. [CrossRef]

53. Blom, J.W.; Osanto, S.; Rosendaal, F.R. The risk of a venous thrombotic event in lung cancer patients: higher risk for adenocarcinoma than squamous cell carcinoma. J. Thromb. Haemost. JTH 2004, 2, 1760-1765. [CrossRef]

54. Huang, G.W.; Nong, H.T.; Nakamura, M.; Kosugi, T. Enhancement of platelet aggregation in patients with nasopharyngeal carcinoma. Auris. Nasus. Larynx 1994, 21, 173-177. [CrossRef]

55. Gregson, J.; Kaptoge, S.; Bolton, T.; Pennells, L.; Willeit, P.; Burgess, S.; Bell, S.; Sweeting, M.; Rimm, E.B.; Kabrhel, C.; et al. Cardiovascular Risk Factors Associated With Venous Thromboembolism. JAMA Cardiol. 2019, 21, 89-93. [CrossRef]

56. Holst, A.G.; Jensen, G.; Prescott, E. Risk factors for venous thromboembolism: results from the Copenhagen City Heart Study. Circulation 2010, 121, 1896-1903. [CrossRef]

57. Forouzanfar, T.; Heymans, M.W.; van Schuilenburg, A.; Zweegman, S.; Schulten, E.A.J.M. Incidence of venous thromboembolism in oral and maxillofacial surgery: A retrospective analysis. Int. J. Oral Maxillofac. Surg. 2010, 39, 256-259. [CrossRef]

58. Bahl, V.; Shuman, A.G.; Hu, H.M.; Jackson, C.R.; Pannucci, C.J.; Alaniz, C.; Chepeha, D.B.; Bradford, C.R. Chemoprophylaxis for venous thromboembolism in otolaryngology. JAMA Otolaryngol.-Head Neck Surg. 2014, 140, 999-1005. [CrossRef]

59. Khorana, A.A.; Francis, C.W.; Culakova, E.; Lyman, G.H. Risk factors for chemotherapy-associated venous thromboembolism in a prospective observational study. Cancer 2005, 104, 2822-2829. [CrossRef]

60. Heit, J.A.; Silverstein, M.D.; Mohr, D.N.; Petterson, T.M.; O’Fallon, W.M.; Melton, L.J. Risk factors for deep vein thrombosis and pulmonary embolism: a population-based case-control study. Arch. Intern. Med. 2000, 160, 809-815. [CrossRef]

61. Lyman, G.H.; Khorana, A.A.; Kuderer, N.M.; Lee, A.Y.; Arcelus, J.I.; Balaban, E.P.; Clarke, J.M.; Flowers, C.R.; Francis, C.W.; Gates, L.E.; et al. Venous thromboembolism prophylaxis and treatment in patients with cancer: American Society of Clinical Oncology clinical practice guideline update. J. Clin. Oncol. Off. J. Am. Soc. Clin. Oncol. 2013, 31, 2189-2204. [CrossRef]

62. Cramer, J.D.; Shuman, A.G.; Brenner, M.J. Antithrombotic Therapy for Venous Thromboembolism and Prevention of Thrombosis in Otolaryngology-Head and Neck Surgery: State of the Art Review. Otolaryngol.-Head Neck Surg. Off. J. Am. Acad. Otolaryngol.-Head Neck Surg. 2018, 158, 627-636. [CrossRef]

63. Robson, A.; Sturman, J.; Williamson, P.; Conboy, P.; Penney, S.; Wood, H. Pre-treatment clinical assessment in head and neck cancer: United Kingdom National Multidisciplinary Guidelines. J. Laryngol. Otol. 2016, 130, S13-S22. [CrossRef]

64. Schulman, S.; Ageno, W.; Konstantinides, S.V. Venous thromboembolism: Past, present and future. Thromb. Haemost. 2017, 117, 1219-1229. [CrossRef]

65. Tukaye, D.N.; Brink, H.; Baliga, R. Venous thromboembolism in cancer patients: Risk assessment, prevention and management. Future Cardiol. 2016, 12, 221-235. [CrossRef]

66. Le Gal, G.; Righini, M.; Wells, P.S. Scoring Systems for Diagnosis of Acute Venous Thromboembolism. Semin. Thromb. Hemost. 2017, 43, 479-485.

67. Hahn, J.; Nordmann-Kleiner, M.; Hoffmann, T.K.; Greve, J. Thrombosis of the internal jugular vein in the ENT-department-Prevalence, causes and therapy: A retrospective analysis. Auris. Nasus. Larynx 2018. [CrossRef] 
68. Watson, H.G.; Keeling, D.M.; Laffan, M.; Tait, R.C.; Makris, M.; British Committee for Standards in Haematology. Guideline on aspects of cancer-related venous thrombosis. Br. J. Haematol. 2015, 170, 640-648. [CrossRef]

69. Di Nisio, M.; Lee, A.Y.Y.; Carrier, M.; Liebman, H.A.; Khorana, A.A.; Subcommittee on Haemostasis and Malignancy. Diagnosis and treatment of incidental venous thromboembolism in cancer patients: guidance from the SSC of the ISTH. J. Thromb. Haemost. JTH 2015, 13, 880-883. [CrossRef]

70. Lyman, G.H.; Bohlke, K.; Khorana, A.A.; Kuderer, N.M.; Lee, A.Y.; Arcelus, J.I.; Balaban, E.P.; Clarke, J.M.; Flowers, C.R.; Francis, C.W.; et al. Venous thromboembolism prophylaxis and treatment in patients with cancer: american society of clinical oncology clinical practice guideline update 2014. J. Clin. Oncol. Off. J. Am. Soc. Clin. Oncol. 2015, 33, 654-656. [CrossRef]

71. Shuman, A.G.; Hu, H.M.; Pannucci, C.J.; Jackson, C.R.; Bradford, C.R.; Bahl, V. Stratifying the risk of venous thromboembolism in otolaryngology. Otolaryngol.-Head Neck Surg. Off. J. Am. Acad. Otolaryngol.-Head Neck Surg. 2012, 146, 719-724. [CrossRef]

72. Watzke, I.; Watzke, H. Thromboembolic risk factors in patients undergoing maxillofacial surgery for malignancies. Oral Surg. Oral Med. Oral Pathol. 1989, 67, 137-140. [CrossRef]

73. Moubayed, S.P.; Eskander, A.; Mourad, M.W.; Most, S.P. Systematic review and meta-analysis of venous thromboembolism in otolaryngology-head and neck surgery. Head Neck 2017, 39, 1249-1258. [CrossRef]

74. Molnar, S.; Guglielmone, H.; Lavarda, M.; Rizzi, M.L.; Jarchum, G. Procoagulant factors in patients with cancer. Hematol. Amst. Neth. 2007, 12, 555-559. [CrossRef]

75. Brayton, J.; Qing, Z.; Hart, M.N.; VanGilder, J.C.; Fabry, Z. Influence of adhesion molecule expression by human brain microvessel endothelium on cancer cell adhesion. J. Neuroimmunol. 1998, 89, 104-112. [CrossRef]

76. Rousseau, A.; Van Dreden, P.; Khaterchi, A.; Larsen, A.K.; Elalamy, I.; Gerotziafas, G.T. Procoagulant microparticles derived from cancer cells have determinant role in the hypercoagulable state associated with cancer. Int. J. Oncol. 2017, 51, 1793-1800. [CrossRef]

77. Saghazadeh, A.; Rezaei, N. Inflammation as a cause of venous thromboembolism. Crit. Rev. Oncol. Hematol. 2016, 99, 272-285. [CrossRef]

78. Posch, F.; Thaler, J.; Zlabinger, G.-J.; Königsbrügge, O.; Koder, S.; Zielinski, C.; Pabinger, I.; Ay, C. Soluble Vascular Endothelial Growth Factor (sVEGF) and the Risk of Venous Thromboembolism in Patients with Cancer: Results from the Vienna Cancer and Thrombosis Study (CATS). Clin. Cancer Res. Off. J. Am. Assoc. Cancer Res. 2016, 22, 200-206. [CrossRef]

79. McVey, J.H. The role of the tissue factor pathway in haemostasis and beyond. Curr. Opin. Hematol. 2016, 23, 453-461. [CrossRef]

80. Mast, A.E. Tissue Factor Pathway Inhibitor: Multiple Anticoagulant Activities for a Single Protein. Arterioscler. Thromb. Vasc. Biol. 2016, 36, 9-14. [CrossRef]

81. Sierko, E.; Wojtukiewicz, M.Z.; Zimnoch, L.; Kisiel, W. Expression of tissue factor pathway inhibitor (TFPI) in human breast and colon cancer tissue. Thromb. Haemost. 2010, 103, 198-204. [CrossRef]

82. Wojtukiewicz, M.Z.; Sierko, E.; Zacharski, L.R.; Zimnoch, L.; Kudryk, B.; Kisiel, W. Tissue factor-dependent coagulation activation and impaired fibrinolysis in situ in gastric cancer. Semin. Thromb. Hemost. 2003, 29, 291-300.

83. Khorana, A.A.; Fine, R.L. Pancreatic cancer and thromboembolic disease. Lancet Oncol. 2004, 5, 655-663. [CrossRef]

84. Wojtukiewicz, M.Z.; Hempel, D.; Kruszewska, J.; Zimnoch, L.; Kisiel, W.; Sierko, E. Erythropoietin receptor and tissue factor are coexpressed in human breast cancer cells. J. BUON Off. J. Balk. Union Oncol. 2015, 20, 1426-1431.

85. Magnus, N.; Garnier, D.; Rak, J. Oncogenic epidermal growth factor receptor up-regulates multiple elements of the tissue factor signaling pathway in human glioma cells. Blood 2010, 116, 815-818. [CrossRef]

86. Wojtukiewicz, M.Z.; Zacharski, L.R.; Ruciñska, M.; Zimnoch, L.; Jaromin, J.; Rózañska-Kudelska, M.; Kisiel, W.; Kudryk, B.J. Expression of tissue factor and tissue factor pathway inhibitor in situ in laryngeal carcinoma. Thromb. Haemost. 1999, 82, 1659-1662. 
87. Christensen, A.; Kiss, K.; Lelkaitis, G.; Juhl, K.; Persson, M.; Charabi, B.W.; Mortensen, J.; Forman, J.L.; Sørensen, A.L.; Jensen, D.H.; et al. Urokinase-type plasminogen activator receptor (uPAR), tissue factor (TF) and epidermal growth factor receptor (EGFR): tumor expression patterns and prognostic value in oral cancer. BMC Cancer 2017, 17, 572. [CrossRef]

88. Chang, M.-C.; Chan, C.-P.; Ho, Y.-S.; Lee, J.-J.; Lin, P.-S.; Lin, B.-R.; Huang, Y.-L.; Hahn, L.-J.; Yeh, H.-W.; Wang, Y.-J.; et al. Signaling pathways for induction of platelet aggregation by SAS tongue cancer cells-A mechanism of hematogenous metastasis. J. Oral Pathol. Med. Off. Publ. Int. Assoc. Oral Pathol. Am. Acad. Oral Pathol. 2009, 38, 434-440. [CrossRef]

89. Welsh, J.; Smith, J.D.; Yates, K.R.; Greenman, J.; Maraveyas, A.; Madden, L.A. Tissue factor expression determines tumour cell coagulation kinetics. Int. J. Lab. Hematol. 2012, 34, 396-402. [CrossRef]

90. Adesanya, M.A.; Maraveyas, A.; Madden, L.A. Cancer microvesicles induce tissue factor-related procoagulant activity in endothelial cells in vitro. Blood Coagul. Fibrinolysis Int. J. Lab. Hematol. 2017, 28, 365-372.

91. Wang, B.; Xiong, S.; Hua, Q.; Chen, C.; Liao, H.; Chen, L.; Yao, W.; Wu, D.; Tao, Z. Tissue factor is strongly expressed in pericarcinomatous tissue in patients with laryngeal carcinoma. Int. J. Clin. Exp. Pathol. 2015, 8, 13719-13724.

92. Kurer, M.A. Protein and mRNA expression of tissue factor pathway inhibitor-1 (TFPI-1) in breast, pancreatic and colorectal cancer cells. Mol. Biol. Rep. 2007, 34, 221-224. [CrossRef]

93. Vairaktaris, E.; Serefoglou, Z.; Yapijakis, C.; Vylliotis, A.; Nkenke, E.; Derka, S.; Vassiliou, S.; Avgoustidis, D.; Neukam, F.W.; Patsouris, E. High gene expression of matrix metalloproteinase-7 is associated with early stages of oral cancer. Anticancer Res. 2007, 27, 2493-2498.

94. Wojtukiewicz, M.Z.; Sierko, E.; Zimnoch, L.; Kozlowski, L.; Kisiel, W. Immunohistochemical localization of tissue factor pathway inhibitor-2 in human tumor tissue. Thromb. Haemost. 2003, 90, 140-146.

95. Nobeyama, Y.; Okochi-Takada, E.; Furuta, J.; Miyagi, Y.; Kikuchi, K.; Yamamoto, A.; Nakanishi, Y.; Nakagawa, H.; Ushijima, T. Silencing of tissue factor pathway inhibitor-2 gene in malignant melanomas. Int. J. Cancer 2007, 121, 301-307. [CrossRef]

96. Sun, Y.; Xie, M.; Liu, M.; Jin, D.; Li, P. Growth suppression of human laryngeal squamous cell carcinoma by adenovirus-mediated tissue factor pathway inhibitor gene 2. Laryngoscope 2006, 116, 596-601. [CrossRef]

97. Thaler, J.; Preusser, M.; Ay, C.; Kaider, A.; Marosi, C.; Zielinski, C.; Pabinger, I.; Hainfellner, J.A. Intratumoral tissue factor expression and risk of venous thromboembolism in brain tumor patients. Thromb. Res. 2013, 131, 162-165. [CrossRef]

98. Wojtukiewicz, M.Z.; Rucinska, M.; Zimnoch, L.; Jaromin, J.; Piotrowski, Z.; Rózanska-Kudelska, M.; Kisiel, W.; Kudryk, B.J. Expression of prothrombin fragment $1+2$ in cancer tissue as an indicator of local activation of blood coagulation. Thromb. Res. 2000, 97, 335-342. [CrossRef]

99. Kalan, A.; Tariq, M.; Harar, R.P.; Gatland, D. Spontaneous internal jugular vein thrombosis and recurrent laryngeal nerve palsy: A rare simultaneous presentation of an occult malignant neoplasm. J. Laryngol. Otol. 1996, 110, 1166-1168. [CrossRef]

100. Wakasaki, T.; Kiyohara, H.; Omori, H.; Nishi, K.; Taguchi, K.; Rikimaru, F.; Toh, S.; Higaki, Y.; Masuda, M. Massive internal jugular vein tumor thrombus derived from squamous cell carcinoma of the head and neck: two case reports. Oral Maxillofac. Surg. 2017, 21, 69-74. [CrossRef]

101. Matsuno, H.; Kozawa, O.; Okada, K.; Ueshima, S.; Matsuo, O.; Uematsu, T. Plasmin generation plays different roles in the formation and removal of arterial and venous thrombus in mice. Thromb. Haemost. 2002, 87, 98-104.

102. Kosugi, T.; Takagi, I.; Ariga, Y.; Okada, S.; Morimitsu, T.; Mihara, H. Fibrinolysis-coagulation system in patients with cancer of the head and neck. Preliminary report. Arch. Otorhinolaryngol. 1982, 236, 211-215. [CrossRef]

103. Jagielska, B.; Symonides, M.; Stachurska, E.; Kawecki, A.; Kraszewska, E. Coagulation disorders in patients with locally advanced head and neck cancer-Should they really be disregarded? Neoplasma 2011, 58, 129-134. [CrossRef]

104. Hundsdorfer, B.; Zeilhofer, H.-F.; Bock, K.P.; Dettmar, P.; Schmitt, M.; Kolk, A.; Pautke, C.; Horch, H.-H. Tumour-associated urokinase-type plasminogen activator (uPA) and its inhibitor PAI-1 in normal and neoplastic tissues of patients with squamous cell cancer of the oral cavity-Clinical relevance and prognostic value. J. Cranio-Maxillo-fac. Surg. Off. Publ. Eur. Assoc. Cranio-Maxillo-fac. Surg. 2005, 33, 191-196. [CrossRef] 
105. Serpa, M.S.; Mafra, R.P.; Queiroz, S.I.M.L.; da Silva, L.P.; deSouza, L.B.; Pinto, L.P. Expression of urokinase-type plasminogen activator and its receptor in squamous cell carcinoma of the oral tongue. Braz. Oral Res. 2018, 32, e93. [CrossRef]

106. Baker, E.A.; Leaper, D.J.; Hayter, J.P.; Dickenson, A.J. Plasminogen activator system in oral squamous cell carcinoma. Br. J. Oral Maxillofac. Surg. 2007, 45, 623-627. [CrossRef]

107. Hayashido, Y.; Hamana, T.; Yoshioka, Y.; Kitano, H.; Koizumi, K.-I.; Okamoto, T. Plasminogen activator/plasmin system suppresses cell-cell adhesion of oral squamous cell carcinoma cells via proteolysis of E-cadherin. Int. J. Oncol. 2005, 27, 693-698.

108. Nozaki, S.; Endo, Y.; Kawashiri, S.; Nakagawa, K.; Yamamoto, E.; Yonemura, Y.; Sasaki, T. Immunohistochemical localization of a urokinase-type plasminogen activator system in squamous cell carcinoma of the oral cavity: association with mode of invasion and lymph node metastasis. Oral Oncol. 1998, 34, 58-62. [CrossRef]

109. Vairaktaris, E.; Yapijakis, C.; Nkenke, E.; Vassiliou, S.; Vylliotis, A.; Nixon, A.M.; Derka, S.; Ragos, V.; Spyridonidou, S.; Tsigris, C.; et al. The 1040C/T polymorphism influencing thermal stability and activity of thrombin activatable fibrinolysis inhibitor is associated with risk for oral cancer. Am. J. Hematol. 2007, 82, 1010-1012. [CrossRef]

110. Sakai, H.; Suzuki, T.; Takahashi, Y.; Ukai, M.; Tauchi, K.; Fujii, T.; Horikawa, N.; Minamimura, T.; Tabuchi, Y.; Morii, M.; et al. Upregulation of thromboxane synthase in human colorectal carcinoma and the cancer cell proliferation by thromboxane A2. FEBS Lett. 2006, 580, 3368-3374. [CrossRef]

111. Mitrugno, A.; Tassi Yunga, S.; Sylman, J.L.; Zilberman-Rudenko, J.; Shirai, T.; Hebert, J.F.; Kayton, R.; Zhang, Y.; Nan, X.; Shatzel, J.J.; et al. The role of coagulation and platelets in colon cancer-associated thrombosis. Am. J. Physiol.-Cell Physiol. 2018, 316, C264-C273. [CrossRef]

112. Pinto, S.; Gori, L.; Gallo, O.; Boccuzzi, S.; Paniccia, R.; Abbate, R. Increased thromboxane A2 production at primary tumor site in metastasizing squamous cell carcinoma of the larynx. Prostaglandins Leukot. Essent. Fatty Acids 1993, 49, 527-530. [CrossRef]

113. Slotman, G.J. Plasma thromboxane A2 and prostacyclin concentrations in squamous cell carcinoma of the head and neck. J. Surg. Oncol. 1988, 38, 33-37. [CrossRef]

114. Camacho, M.; Piñeiro, Z.; Alcolea, S.; García, J.; Balart, J.; Terra, X.; Avilés-Jurado, F.-X.; Soler, M.; Quer, M.; León, X.; et al. Prostacyclin-synthase expression in head and neck carcinoma patients and its prognostic value in the response to radiotherapy. J. Pathol. 2015, 235, 125-135. [CrossRef]

115. Mir Seyed Nazari, P.; Riedl, J.; Pabinger, I.; Ay, C. The role of podoplanin in cancer-associated thrombosis. Thromb. Res. 2018, 164 (Suppl. 1), S34-S39. [CrossRef]

116. Kubouchi, Y.; Yurugi, Y.; Wakahara, M.; Sakabe, T.; Haruki, T.; Nosaka, K.; Miwa, K.; Araki, K.; Taniguchi, Y.; Shiomi, T.; et al. Podoplanin expression in cancer-associated fibroblasts predicts unfavourable prognosis in patients with pathological stage IA lung adenocarcinoma. Histopathology 2018, 72, 490-499. [CrossRef]

117. Suchanski, J.; Tejchman, A.; Zacharski, M.; Piotrowska, A.; Grzegrzolka, J.; Chodaczek, G.; Nowinska, K.; Rys, J.; Dziegiel, P.; Kieda, C.; et al. Podoplanin increases the migration of human fibroblasts and affects the endothelial cell network formation: A possible role for cancer-associated fibroblasts in breast cancer progression. PLoS ONE 2017, 12, e0184970. [CrossRef]

118. Yuan, P.; Temam, S.; El-Naggar, A.; Zhou, X.; Liu, D.D.; Lee, J.J.; Mao, L. Overexpression of podoplanin in oral cancer and its association with poor clinical outcome. Cancer 2006, 107, 563-569. [CrossRef]

119. Martín-Villar, E.; Scholl, F.G.; Gamallo, C.; Yurrita, M.M.; Muñoz-Guerra, M.; Cruces, J.; Quintanilla, M. Characterization of human PA2.26 antigen (T1alpha-2, podoplanin), a small membrane mucin induced in oral squamous cell carcinomas. Int. J. Cancer 2005, 113, 899-910. [CrossRef]

120. Kreppel, M.; Scheer, M.; Drebber, U.; Ritter, L.; Zöller, J.E. Impact of podoplanin expression in oral squamous cell carcinoma: Clinical and histopathologic correlations. Virchows Arch. Int. J. Pathol. 2010, 456, 473-482. [CrossRef]

121. Pépin, M.; Kleinjan, A.; Hajage, D.; Büller, H.R.; Di Nisio, M.; Kamphuisen, P.W.; Salomon, L.; Veyradier, A.; Stepanian, A.; Mahé, I. ADAMTS-13 and von Willebrand factor predict venous thromboembolism in patients with cancer. J. Thromb. Haemost. JTH 2016, 14, 306-315. [CrossRef]

122. Franchini, M.; Frattini, F.; Crestani, S.; Bonfanti, C.; Lippi, G. von Willebrand factor and cancer: A renewed interest. Thromb. Res. 2013, 131, 290-292. [CrossRef] 
123. Sweeney, J.D.; Killion, K.M.; Pruet, C.F.; Spaulding, M.B. Von Willebrand factor in head and neck cancer. Cancer 1990, 66, 2387-2389. [CrossRef]

124. Paczuski, R.; Bialkowska, A.; Kotschy, M.; Burduk, D.; Betlejewski, S. Von Willebrand factor in plasma of patients with advanced stages of larynx cancer. Thromb. Res. 1999, 95, 197-200. [CrossRef]

125. Loghmani, H.; Conway, E.M. Exploring traditional and nontraditional roles for thrombomodulin. Blood 2018, 132, 148-158. [CrossRef]

126. Oikawa, T.; Kushuhara, M.; Ishikawa, S.; Hitomi, J.; Kono, A.; Iwanaga, T.; Yamaguchi, K. Production of endothelin-1 and thrombomodulin by human pancreatic cancer cells. Br. J. Cancer 1994, 69, 1059-1064. [CrossRef]

127. Hamatake, M.; Ishida, T.; Mitsudomi, T.; Akazawa, K.; Sugimachi, K. Prognostic value and clinicopathological correlation of thrombomodulin in squamous cell carcinoma of the human lung. Clin. Cancer Res. Off. J. Am. Assoc. Cancer Res. 1996, 2, 763-766.

128. Tabata, M.; Sugihara, K.; Yonezawa, S.; Yamashita, S.; Maruyama, I. An immunohistochemical study of thrombomodulin in oral squamous cell carcinoma and its association with invasive and metastatic potential. J. Oral Pathol. Med. Off. Publ. Int. Assoc. Oral Pathol. Am. Acad. Oral Pathol. 1997, 26, 258-264. [CrossRef]

129. Hernández Gaspar, R.; de los Toyos, J.R.; Alvarez Marcos, C.; Riera, J.R.; Sampedro, A. Quantitative immunohistochemical analyses of the expression of E-cadherin, thrombomodulin, CD44H and CD44v6 in primary tumours of pharynx/larynx squamous cell carcinoma and their lymph node metastases. Anal. Cell. Pathol. J. Eur. Soc. Anal. Cell. Pathol. 1999, 18, 183-190. [CrossRef]

130. Cui, C.-J.; Wang, G.-J.; Yang, S.; Huang, S.-K.; Qiao, R.; Cui, W. Tissue Factor-bearing MPs and the risk of venous thrombosis in cancer patients: A meta-analysis. Sci. Rep. 2018, 8, 1675. [CrossRef]

131. Ren, J.G.; Man, Q.W.; Zhang, W.; Li, C.; Xiong, X.P.; Zhu, J.Y.; Wang, W.M.; Sun, Z.J.; Jia, J.; Zhang, W.F.; et al. Elevated Level of Circulating Platelet-derived Microparticles in Oral Cancer. J. Dent. Res. 2016, 95, 87-93. [CrossRef]

132. Sierko, E.; Sobierska, M.; Zabrocka, E.; Myśliwiec, M.; Kruszewska, J.; Lipska, A.; Radziwon, P.; Wojtukiewicz, M.Z. Endothelial Microparticles and Blood Coagulation Activation in Head and Neck Cancer Patients Undergoing Radiotherapy or Radiochemotherapy. Vivo Athens Greece 2019, 33, 627-632. [CrossRef]

133. Aharon, A.; Brenner, B. Microparticles, thrombosis and cancer. Best Pract. Res. Clin. Haematol. 2009, 22, 61-69. [CrossRef]

134. Branchford, B.R.; Carpenter, S.L. The Role of Inflammation in Venous Thromboembolism. Front. Pediatr. 2018, 6, 142. [CrossRef]

135. Grignani, G.; Maiolo, A. Cytokines and hemostasis. Haematologica 2000, 85, 967-972.

136. Gallo, O.; Pinto, S.; Boccuzzi, S.; Dilaghi, M.; Gallina, E.; Attanasio, M.; Gori, A.M.; Martini, F.; Abbate, R. Monocyte tumor necrosis factor production in head and neck squamous cell carcinoma. Laryngoscope 1992, 102, 447-450. [CrossRef]

137. Parks, R.R.; Yan, S.D.; Huang, C.C. Tumor necrosis factor-alpha production in human head and neck squamous cell carcinoma. Laryngoscope 1994, 104, 860-864. [CrossRef]

138. Nakano, Y.; Kobayashi, W.; Sugai, S.; Kimura, H.; Yagihashi, S. Expression of tumor necrosis factor-alpha and interleukin-6 in oral squamous cell carcinoma. Jpn. J. Cancer Res. Gann 1999, 90, 858-866. [CrossRef]

139. Scheff, N.N.; Ye, Y.; Bhattacharya, A.; MacRae, J.; Hickman, D.N.; Sharma, A.K.; Dolan, J.C.; Schmidt, B.L. Tumor necrosis factor alpha secreted from oral squamous cell carcinoma contributes to cancer pain and associated inflammation. Pain 2017, 158, 2396-2409. [CrossRef]

140. Gallo, O.; Gori, A.M.; Attanasio, M.; Martini, F.; Giusti, B.; Boddi, M.; Gallina, E.; Fini, O.; Abbate, R. Interleukin-1 beta and interleukin- 6 release by peripheral blood monocytes in head and neck cancer. $\mathrm{Br}$. J. Cancer 1993, 68, 465-468. [CrossRef]

141. Tsai, C.C.; Chen, C.C.; Lin, C.C.; Chen, C.H.; Lin, T.S.; Shieh, T.Y. Interleukin-1 beta in oral submucous fibrosis, verrucous hyperplasia and squamous cell carcinoma tissues. Kaohsiung J. Med. Sci. 1999, 15, 513-519.

142. Thomas, G.R.; Chen, Z.; Leukinova, E.; Van Waes, C.; Wen, J. Cytokines IL-1 alpha, IL-6, and GM-CSF constitutively secreted by oral squamous carcinoma induce down-regulation of CD80 costimulatory molecule expression: restoration by interferon gamma. Cancer Immunol. Immunother. CII 2004, 53, 33-40. [CrossRef]

143. Wang, Y.-F.; Chang, S.-Y.; Tai, S.-K.; Li, W.-Y.; Wang, L.-S. Clinical significance of interleukin-6 and interleukin-6 receptor expressions in oral squamous cell carcinoma. Head Neck 2002, 24, 850-858. [CrossRef] 
144. Khorana, A.A.; Ahrendt, S.A.; Ryan, C.K.; Francis, C.W.; Hruban, R.H.; Hu, Y.C.; Hostetter, G.; Harvey, J.; Taubman, M.B. Tissue factor expression, angiogenesis, and thrombosis in pancreatic cancer. Clin. Cancer Res. Off. J. Am. Assoc. Cancer Res. 2007, 13, 2870-2875. [CrossRef]

145. Chen, Z.; Malhotra, P.S.; Thomas, G.R.; Ondrey, F.G.; Duffey, D.C.; Smith, C.W.; Enamorado, I.; Yeh, N.T.; Kroog, G.S.; Rudy, S.; et al. Expression of proinflammatory and proangiogenic cytokines in patients with head and neck cancer. Clin. Cancer Res. Off. J. Am. Assoc. Cancer Res. 1999, 5, 1369-1379.

146. Johnstone, S.; Logan, R.M. Expression of vascular endothelial growth factor (VEGF) in normal oral mucosa, oral dysplasia and oral squamous cell carcinoma. Int. J. Oral Maxillofac. Surg. 2007, 36, 263-266. [CrossRef]

147. Eisma, R.J.; Spiro, J.D.; Kreutzer, D.L. Vascular endothelial growth factor expression in head and neck squamous cell carcinoma. Am. J. Surg. 1997, 174, 513-517. [CrossRef]

148. Falanga, A.; Marchetti, M.; Evangelista, V.; Manarini, S.; Oldani, E.; Giovanelli, S.; Galbusera, M.; Cerletti, C.; Barbui, T. Neutrophil activation and hemostatic changes in healthy donors receiving granulocyte colony-stimulating factor. Blood 1999, 93, 2506-2514.

149. Mann, E.A.; Spiro, J.D.; Chen, L.L.; Kreutzer, D.L. Cytokine expression by head and neck squamous cell carcinomas. Am. J. Surg. 1992, 164, 567-573. [CrossRef]

150. Plantureux, L.; Crescence, L.; Dignat-George, F.; Panicot-Dubois, L.; Dubois, C. Effects of platelets on cancer progression. Thromb. Res. 2018, 164 (Suppl. 1), S40-S47. [CrossRef]

151. Folkman, J. Proceedings: Tumor angiogenesis factor. Cancer Res. 1974, 34, 2109-2113.

152. Shigetomi, S.; Imanishi, Y.; Shibata, K.; Sakai, N.; Sakamoto, K.; Fujii, R.; Habu, N.; Otsuka, K.; Sato, Y.; Watanabe, Y.; et al. VEGF-C/Flt-4 axis in tumor cells contributes to the progression of oral squamous cell carcinoma via upregulating VEGF-C itself and contactin-1 in an autocrine manner. Am. J. Cancer Res. 2018, 8, 2046-2063. [PubMed]

153. Subarnbhesaj, A.; Miyauchi, M.; Chanbora, C.; Mikuriya, A.; Nguyen, P.T.; Furusho, H.; Ayuningtyas, N.F.; Fujita, M.; Toratani, S.; Takechi, M.; et al. Roles of VEGF-Flt-1 signaling in malignant behaviors of oral squamous cell carcinoma. PLoS ONE 2017, 12, e0187092. [CrossRef] [PubMed]

154. Chen, R.; Jin, G.; Li, W.; McIntyre, T.M. Epidermal Growth Factor (EGF) Autocrine Activation of Human Platelets Promotes EGF Receptor-Dependent Oral Squamous Cell Carcinoma Invasion, Migration, and Epithelial Mesenchymal Transition. J. Immunol. Baltim. Md 1950 2018, 201, 2154-2164. [CrossRef] [PubMed]

155. Dai, W.; Li, Y.; Zhou, Q.; Xu, Z.; Sun, C.; Tan, X.; Lu, L. Cetuximab inhibits oral squamous cell carcinoma invasion and metastasis via degradation of epidermal growth factor receptor. J. Oral Pathol. Med. Off. Publ. Int. Assoc. Oral Pathol. Am. Acad. Oral Pathol. 2014, 43, 250-257. [CrossRef] [PubMed]

156. Zhang, H.; Sun, J.-D.; Yan, L.-J.; Zhao, X.-P. PDGF-D/PDGFR $\beta$ promotes tongue squamous carcinoma cell (TSCC) progression via activating p38/AKT/ERK/EMT signal pathway. Biochem. Biophys. Res. Commun. 2016, 478, 845-851. [CrossRef] [PubMed]

157. Chen, C.; Zimmermann, M.; Tinhofer, I.; Kaufmann, A.M.; Albers, A.E. Epithelial-to-mesenchymal transition and cancer stem(-like) cells in head and neck squamous cell carcinoma. Cancer Lett. 2013, 338, 47-56. [CrossRef] [PubMed]

158. Wu, F.; Weigel, K.J.; Zhou, H.; Wang, X.-J. Paradoxical roles of TGF- $\beta$ signaling in suppressing and promoting squamous cell carcinoma. Acta Biochim. Biophys. Sin. 2018, 50, 98-105. [CrossRef] [PubMed]

159. Palumbo, J.S.; Talmage, K.E.; Massari, J.V.; La Jeunesse, C.M.; Flick, M.J.; Kombrinck, K.W.; Jirousková, M.; Degen, J.L. Platelets and fibrin(ogen) increase metastatic potential by impeding natural killer cell-mediated elimination of tumor cells. Blood 2005, 105, 178-185. [CrossRef]

160. Egan, K.; Cooke, N.; Kenny, D. Living in shear: Platelets protect cancer cells from shear induced damage. Clin. Exp. Metastasis 2014, 31, 697-704. [CrossRef]

161. Mezouar, S.; Darbousset, R.; Dignat-George, F.; Panicot-Dubois, L.; Dubois, C. Inhibition of platelet activation prevents the P-selectin and integrin-dependent accumulation of cancer cell microparticles and reduces tumor growth and metastasis in vivo. Int. J. Cancer 2015, 136, 462-475. [CrossRef]

162. Papa, M.L.; Capasso, F.; Pudore, L.; Torre, S.; Mango, S.; Russo, V.; Delrio, P.; Palaia, R.; Ruffolo, F.; d'Eufemia, M.D.; et al. Thromboelastographic profiles as a tool for thrombotic risk in digestive tract cancer. Exp. Oncol. 2007, 29, 111-115. [PubMed] 
163. Crowley, M.P.; Crowely, M.P.; Quinn, S.; Coleman, E.; Eustace, J.A.; Gilligan, O.M.; O'Shea, S.I.; Shea, S.I.O. Differing coagulation profiles of patients with monoclonal gammopathy of undetermined significance and multiple myeloma. J. Thromb. Thrombolysis 2015, 39, 245-249. [CrossRef] [PubMed]

164. Zanetto, A.; Senzolo, M.; Vitale, A.; Cillo, U.; Radu, C.; Sartorello, F.; Spiezia, L.; Campello, E.; Rodriguez-Castro, K.; Ferrarese, A.; et al. Thromboelastometry hypercoagulable profiles and portal vein thrombosis in cirrhotic patients with hepatocellular carcinoma. Dig. Liver Dis. Off. J. Ital. Soc. Gastroenterol. Ital. Assoc. Study Liver 2017, 49, 440-445. [CrossRef] [PubMed]

(C) 2019 by the authors. Licensee MDPI, Basel, Switzerland. This article is an open access article distributed under the terms and conditions of the Creative Commons Attribution (CC BY) license (http://creativecommons.org/licenses/by/4.0/). 